Historic, Archive Document

Do not assume content reflects current scientific knowledge, policies, or practices. 



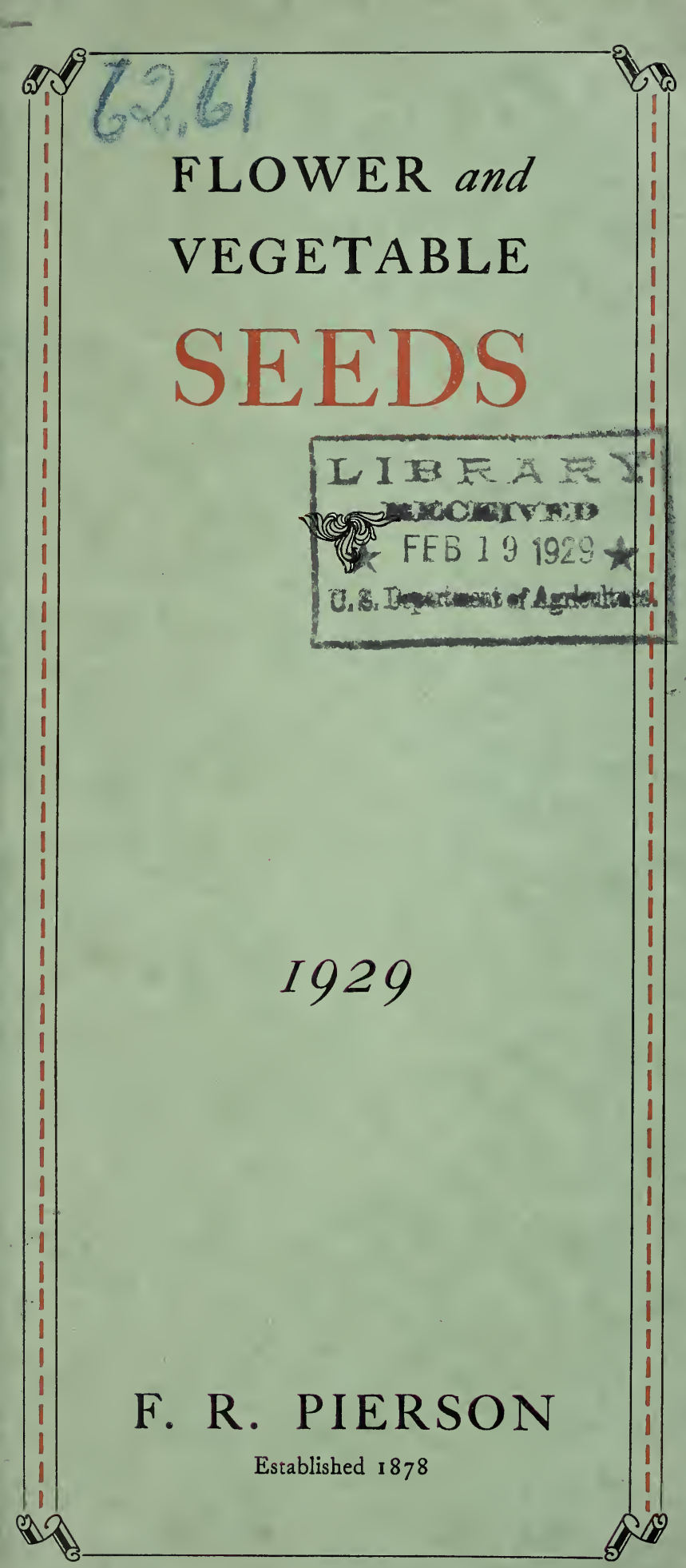





\section{Flower and Vegetable}

\section{S E E D S}

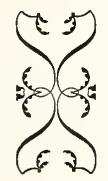

1929

\section{F . R . P I E R S O N}

Tarrytozen, New York

TELEPHONES

Office and Flower Shop........... Tarrytown 48 Rose Houses, Scarborough.......... Ossining 276 Nurseries and Landscape Dept....... Ossining 286 Rockwood Hall Greenhouses....... Tarrytown 216 


\section{WE DELIVER FREE}

To any post office in the United States, at catalogue prices, all Flower and Vegetable Seeds in packets, ounces, and quarter pounds.

When seeds by the pound and upwards are ordered to be sent by mail, postage must be added at parcel-post zone rates. A quart of Peas, Beans, or Corn weighs two pounds. Canadian shipments require $14 \mathrm{c}$. per pound or fraction thereof for postage.

When sent by freight or express, purchaser pays transit charges on all Seeds in bulk, Fertilizers, Insecticides, and Greenhouse and Garden Supplies, except where otherwise noted.

We make no charge for boxes, packing, or cartage, except where Peas, Beans, and Corn and Grass Seed are ordered in large quantities, when 50c. extra must be added for every two bushels to cover cost of bags.

New customers, unknown to us, who desire to open accounts, must give satisfactory reference as to their responsibility. Orders from unknown purchasers, unaccompanied by remittance or satisfactory references, will be shipped by express or Parcel Post, C. O. D.

Remittance can be made with perfect safety by check, post office or express money order, or cash can be sent in registered letter; fractional parts of a dollar in postage stamps. Cash should never be sent in unregistered letters. Under no circumstances will we assume any responsibility for the safe carriage of money sent in unregistered letters.

The prices quoted in this catalogue are net. We reserve the right to advance or change prices without notice should current conditions require it.

Our seeds are tested seeds of the very best quality obtainable, and our prices are fixed at the very lowest rates consistent with high quality. While we exercise the greatest care to have all our seeds pure and reliable, we give no warranty, expressed or implied, and will in no way be responsible for the crop. If purchaser does not accept our goods on these conditions, goods must be returned at once. 
ACHILLEA (Milfoil, or Yarrow)

Ptarmica fl. pl. "The Pearl." One of the best hardy white perennials. Pure white flowers, borne in the greatest profusion the entire summer. Two feet high. Pkt., 25c.

\section{ACONITUM}

Napellus (Monkshood). A hardy perennial, with odd-shaped blue and white flowers. Pkt., 15c.

\section{AGERATUM}

Blue Perfection. Dwarf. Dark blue. Pkt., 10c.

Blue Star. Very compact. Only four to six inches high. Light blue. Pkt., 25c.

Little Dorrit. Dwarf. Blue, white. Each, pkt., 10c.

\section{ALYSSUM}

Sweet (Maritimum). White. Pkt., 5c.; oz., 50c. Tom Thumb (Compactum erectum, or Little Gem). White Very dwarf, growing only three to four inches high. Pkt., 10c.; oz., 75c.

Saxatile compactum (Basket of Gold). A very showy hardy perennial. Grows about a foot in height, and bears bright yellow flowers. Splendid for rock work. Pkt., 10c.

ANCHUSA (Bugloss)

Italica, Dropmore variety. One of the best of the blue perennials. Produces gentian-blue flowers the entire summer. Grows five to six feet high. Pkt., $15 \mathrm{c}$.

\section{ANTIRRHINUM}

This is becoming more popular every year, both for cutting and greenhouse culture in winter.

Tall and Semi-dwarf Large-flowering Varieties. Crimson King. Beautiful rich crimson. Very large flower. Pkt., $15 \mathrm{c}$.

Delila. Pink, yellow and white. Pkt., 15c.

Firefly. Crimson and yellow. Pkt., 15c.

Luteum (Golden King). Bright yellow. Pkt., 15c. Nelrose. Silvery pink. Very long stems. Excellent for greenhouse. Pkt., 50c.

Queen Victoria. Pure white. Very large. Excellent for forcing. Pkt., 10c.

Roseum. Deep rosy pink. Pkt., 15c.

Silver Pink. A splendid semi-dwarf variety. Deliicate silvery pink. One of the best varieties for forcing. Pkt., $\$ 1.00$.

Venus. Delicate pink, with white throat. Pkt., 15c. Finest Mixed. Pkt., 10c.

\section{Dwarf Varieties.}

Tom Thumb. All colors, finest mixed. Pkt., 15c. 
AQUILEGIA (Columbine)

Californica Hybrids. Yellow and orange shades. Pkt., 15c.

Cerulea. Sky-blue and white. Very large. Pkt., 25c.

Chrysantha. Bright yellow. Pkt., 15c.

Long-spurred Hybrids. Choice mixed. Pkt., 25c. Nivea grandiflora. Large pure white flowers. Pkt., 10c.

Skinneri. Scarlet, tipped green. Striking. Pkt., $25 \mathrm{c}$.

\section{ARABIS (Rock Cress)}

Alpina. White. Single. Fine for edging and for rock gardens. Pkt., $10 \mathrm{c}$.

ARMERIA (Sea Pink, or Thrift)

Excellent for rockery and border. Nine inches high.

Formosa. Light pink. Pkt., 15c.

\section{ASPARAGUS}

Plumosus nanus. Pkt., 25c.; 100 seeds, $\$ 1.00$.

Sprengeri. Pkt., 10c.; 100 seeds, 50c.

ASTER, Annual

Astermum. A splendid giant-flowering aster. The plants grow compact, about two feet high, with long, strong stems. Midseason.

Separate colors. White, rose-pink, lavender. Each, pkt., 15c.; I/4 Oz., $75 \mathrm{c}$.

Finest mixed. Pkt., 15c.; I/4 oz., 60c.

Branching. A grand aster for cutting. Very free bloomer. Flowers of the largest size, with long stems.

Separate colors. White, shell-pink, lavender, rose, crimson, purple. Each, pkt., 10c.; 1/4 oz., 60c.

Finest mixed. Pkt., 10c.; $1 / 4$ oz., $50 \mathrm{c}$.

Enchantress. A very desirable midseason aster. Of upright growth, producing full, double, light pink flowers of the color of an Enchantress carnation. Pkt., 15c.

Heart of France. The plants are of the branching type. The flowers are large and full, rich deep ruby red, borne on long, strong stems. Pkt., 20c.

King. A distinct class, or type, of aster. The plant makes a sturdy growth of branching habit, similar to the late Branching aster. The flowers are quite distinct resembling the quilled varieties, but the petals are larger and broader, the center petals curling and incurving toward the center.

Separate colors. White, shell-pink, violet, rose, Each, pkt., 10c.; $1 / 4$ oz., 60 c.

Finest mixed. Pkt., 10c., 1/4 oz., 50c.

Lavender Gem. A beautiful midseason aster of the Comet type. The flowers are a true lavender shade. Petals are gracefully curled and twisted, and are borne on strong stems. Pkt., $15 \mathrm{c}$. 


\section{ASTER-Continued}

Peerless Pink. A strong grower, of free branching habit. Flowers large and globular in shape, very double, measuring four to five inches across. Color beautiful shell-pink. Comes into bloom about the middle of August, being at its best the early part of September. Pkt., 15c.

Pink Beauty. A strong, vigorous upright grower, twenty-four to thirty inches. Flowers soft delicate pink, averaging four inches across, borne profusely on long, strong stems. A fine midseason aster.

Pkt., 15c.

\section{ASTER, Hardy Perennial}

Alpinus. Indispensable for the rockery or edging of hardy borders.

Separate colors. White, blue. Each, pkt., 15c.

BALSAM, Pierson's Prize

White (Alba Perfecta). As double and perfect as a camellia. Extra choice. Pkt., 10c.; r/4 oz., 50c.

Separate colors. Scarlet, apple blossom, blood-red, rose color. Each, pkt., 10c.; I/4 oz., 50c.

Finest mixed. All colors. Pkt., $10 \mathrm{c}$.; $1 / 4$ oz., $40 \mathrm{c}$.

\section{BELLIS PERENNIS (English Daisy)}

Giant Pink. Larger than Longfellow. Pkt., 15c.

Giant White. Larger than Snowball. Pkt., 15c.

Longfellow. A fine double pink. Pkt., 10c.

Montrosa fl. pl. A magnificent strain, producing double flowers of enormous size.

Separate colors. White, pink. Each, pkt., 25c.

Snowball. A fine white. Pkt., 10c.

\section{BEGONIA SEMPERFLORENS}

The ever-blooming Begonia. One of the finest of all plants for summer bedding. We offer some extra choice varieties.

Erfordia. Flowers lovely dark rose-pink-about the shade of Gloire de Lorraine. Finest habit and best bloomer of all this type. A constant mass of bloom, being covered with flowers all summer. Dark metallic bronze-like foliage. Pkt., 50c.

Gracilis (Rosea). Bright pink-an exqursite color. Very distinct. Pkt., 25c.

Magnifica. Improved Vernon. Carmine-scarief Flowers large. Very fine. Pkt., 25c.

Prima Donna. A splendid Begonia. Flowers large, clear rose, shading to carmine. Plants compact. Fine for bedding or pot culture. Pkt., 25c.

BOCCONIA (Plume Poppy)

Cordata. Well adapted for shrubbery beds for perennial border or fine as single specimens. Six to eight feet. Flowers buff-colored. Pkt., 10c. 
BOLTONIA (False Chamomile)

Asteroides. Single white aster-like flowers. Fine for cutting. Five to seven feet. Pkt., 15c.

Latisquama. Pink. Four to six feet. Pkt., 15c.

\section{CALCEOLARIA HYBRIDA}

Covent Garden Strain. Choice mixed. Pkt., 50c.

CALENDULA (Pot Marigold)

Ball's Gold. Dark golden yellow, fine for cutting. Pkt., 25c.; 1/8 oz., 75c.

Ball's Orange. Bright glowing orange. Pkt., 25c.; I $/ 8$ oz., $75 \mathrm{c}$.

Meteor. Yellow, striped orange. Pkt., 10c.; oz., 40c. Orange King. Deep orange. Extra selected strain. Pkt., 15c.; 1/4 oz., 75c.

CALLIOPSIS (Coreopsis)

Finest mixed annual varieties. Pkt., 10c.; oz., 50c.

CAMPANULA (Bell Flower)

Calycanthema Medium. (Cup and Saucer Canterbury Bell). One of the showiest and most beautiful of the hardy perennials.

Separate colors. Blue, Lilacina, white, pink. Each, pkt., $15 \mathrm{c}$.

Finest mixed. Pkt., $15 \mathrm{c}$.

Carpatica. A fine hardy perennial. Grows in tufts, six inches high. In bloom all summer.

Separate colors. White, blue. Each, pkt., 15c.

Persicifolia grandiflora. Blooms during the entire summer, throwing up beautiful spikes of single flowers. One of the finest hardy plants.

Separate colors. White, blue. Each, pkt., 25c.

Pyramidalis. Very desirable for hardy borders, also fine for forcing. In pots make excellent specimens.

Separate colors. White, blue. Each, pkt., 15c.

CANDYTUFT (Iberis), Annual Varieties

Carminea. Carter's carmine. Pkt., 10c.; oz., 50c.

Crimson. Pkt., 10c.; oz., 50c.

Giant Hyacinth-flowered. Pure white, with large trusses. Dwarf. Pkt., 10c.; oz., 75c.

All colors mixed. Pkt., 10c.; oz., 40c.

For perennial varieties, see Iberis.

CANTERBURY BELLS. See Campanula, above.

\section{CARNATION}

Margaret. A summer-blooming carnation, to be had in flower within four months after sowing. Seed sown early will bloom by July.

Finest mixed. Extra quality. Pkt., 15c.; 1/4 oz., 75c. Giant Margaret. An improved strain. Flowers often measure three inches across. Pkt., 25c.

Chabaud's Double Perpetual. A popular hardy class of garden pinks, which bloom freely and abundantly in five to six months after being sown.

Finest mixed. Pkt., 25c. 


\section{CASTOR OIL BEAN (Ricinus)}

Borboniensis arboreus. The tallest of all, growing fifteen feet high. Green-leaved. Pkt., 10c.; oz., 30c. Cambodgiensis. Quite dwarf, growing only six to eight feet high. Leaves nearly black, very richly colored. Pkt., 10c.; oz., 35c.

Zanzibariensis. A gigantic-leaved variety, growing ten or twelve feet high. Pkt., 10c.; oz., 30c.

\section{CELOSIA CRISTATA (Cockscomb)}

Glasgow Prize. The finest of all the cockscombs. Grows only twelve inches high, producing crimson combs of the very largest size. Pkt., 15c.

Nana compacta. Finest mixed. Pkt., 10c.

CELOSIA PYRAMIDALIS (Feathered Cockscomb)

Childsi (Chinese Wool Flower). A very attractive type of Celosia plumosa. The blooms, instead of being of pyramidal shape, are formed in large globular heads, like balls of wool or chenille.

Separate colors. Crimson, dark pink, yellow. Each, pkt., $15 \mathrm{c}$.

Thompsoni magnifica (Improved Feathered Cockscomb). Of pyramidal growth. Fine for bedding.

Crimson. One of the finest of the feathered cockscombs. Brilliant crimson. Extra. Pkt., 15c.

Jaune d'Or. Fine golden yellow. Pkt., 15c.

Finest mixed. Pkt., 15c.

\section{CENTAUREA}

Cyanus (Cornflower, or Ragged Sailor). A very well-known annual, flowering freely in almost any situation.

Double Blue. The most popular color in this favorite flower. Pkt., 10c.; $1 / 4$ oz., 30c.

Double finest mixed. All colors. Pkt., 10c.; I/4 oz., $25 \mathrm{c}$.

Imperialis (Royal Sweet Sultan). Finest mixed, all colors. Pkt., 10c.

Gymnocarpa (Dusty Miller). Finely divided fernlike silvery gray foliage. Pkt., 10c.

Moschata (Sweet Sultan). Very sweet-scented. Indispensable for cutting. Finest mixed, all colors. Pkt., 10c.

CHRYSANTHEMUM, Annual Varieties.

Evening Star, or Helios. Flowers large, measuring three inches across; rich, bright golden yellow. Fine for cutting. Pkt., 10c.

Inodorum plenissimum. Double white flowers, borne in large clusters. Fine for cutting. Pkt., 10c.

Morning Star. Primrose, with golden yellow center. Fkt., 10c.

Northern Star. Flowers extra large and showy; white, with yellow center, dark disc. Pkt., 10c.

The Sultan. Crimson-maroon, golden center surrounding eye. Pkt., 10c.

Finest mixed. All colors. Pkt., 10c. 


\section{CINERARIA}

Pierson's Prize Exhibition. Our strain of this important showy greenhouse plant is obtained from a prize European collection. Finest mixed, all colors. Pkt., $50 \mathrm{c}$.

Stellata. Small-flowering, for cutting and decorative purposes. Pkt., 50c.

\section{COBEA}

Scandens. One of the finest summer climbers.

Blue. Pkt., 10c.; I/4 oz., 25c.

White. Pkt., 15c.; 1/4 oz., 50c.

\section{CONVOLVULUS}

Major. See Morning Glory, page 13.

\section{COREOPSIS}

Lanceolata grandiflora. One of the finest hardy garden plants. Large bright yellow flowers, borne on long stems. Very showy and valuable for cutting. Two to three feet high. Pkt., 10c.; $1 / 4$ oz., 25c.

\section{COSMOS}

Giant-flowered. One of the showiest plants in late autumn.

Klondyke. Large orange-colored flowers borne on long stems. Pkt., 15c.

Lady Lenox. Beautiful flowers of immense size, borne on long stems. Vigorous grower.

Separate colors. White, pink. Each, pkt., 10c.; $1 / 4$ oz., 40c.

Large Early-flowering. Very early. Flowers frequently are twice as large as those produced by any early-flowering strain previously known.

Separate colors. Rose, white. Each, pkt., 10c.; 1/4 oz., 50c.

Finest mixed. All colors. Pkt., 10c.; $1 / 4$ oz., 40c. Double Crested. A distinct cosmos. The flowers are beautifully crested, which gives them a dainty and striking appearance. Not all of the flowers are double, but a large percentage come true from seed. The remainder are single and of large size.

Pink Beauty. Delicate pink. Pkt., 20c.

White Queen. Pure white. Pkt., 20c.

\section{CYCLAMEN PERSICUM}

Covent Garden Strain. The very choicest strain of this beautiful flower obtainable. Flowers of the largest size and most brilliant colors. Pkt., 50c.

DAISY, Shasta

Alaska. This giant California Daisy produces magnificent pure white flowers four inches or more in diameter, on stems one and a half to two feet in length. It is perfectly hardy and flowers freely. Pkt., 25c.

DELPHINIUM (Larkspur)

Belladonna Improved. A beautiful hardy larkspur, producing long spikes of lovely clear turquoise-blue flowers. Pkt., 25c.

Bellamosum. Rich deep blue. Similar in form and habit to Belladonna. Pkt., 25c. 
DELPHINIUM (Larkspur)-Continued

Dreer's DeLuxe Hybrids. The plants are of vigorous habit, with large spikes of enormous flowers, shading from the palest lavender to the richest oxford blue as well as pastel shades. Pkt., $25 \mathrm{c}$.

Fanny Stormouth. Light azure blue. Pkt., 25c.

Formosum cœlestinum. A beautiful variety. Skyblue, with white center. Pkt., 25c.

Gold Medal Hybrids. Strong, vigorous growers. Immense flower spikes, mostly shades of blue. Pkt., $15 \mathrm{c}$.

\section{DIANTHUS}

Barbatus. See Sweet William, page 22.

Chinensis fl. pl. (China or Indian Pink). Finest double mixed. Pkt., 10c.

Diadematus fl. pl. (China or Indian Pink). Finest in various colors, richly edged and marbled. Pkt., $10 \mathrm{c}$.

Heddewigi. Single. Large flowers in beautiful rich colors. Pkt., 10c.

Imperialis fl. pl. (Imperial Pink). A superb mixture of these charming varieties. Pkt., 10c.

Latifolius atrococcineus fl. pl. (Ever-blooming hybrid Sweet William). Double. Blooms all summer. Brilliant fiery crimson. Very fine. Pkt., $15 \mathrm{c}$.

DIDISCUS (Blue Lace Flower)

Cœruleus. A very pretty annual, growing about two feet high, bearing umbel-shaped pale bluish lavender lace-like flowers two to three inches across. Blooms from July to October. Very desirable for cutting. Pkt., 20c.

\section{DIGITALIS (Foxglove)}

One of the showiest and most important of all hardy herbaceous plants.

Gloxinæflora. A beautiful class, with large individual flowers, variously spotted and penciled.

Separate colors. White, rose, purple. Each, pkt., $10 \mathrm{c}$; $1 / 4$ oz., $50 \mathrm{c}$.

Finest mixed. Pkt., 10c.; 1/4 oz., 40c.

Ivery's New Spotted. A very much improved strain. An excellent variety of colors. Pkt., 10c.; I/4 oz., $50 \mathrm{c}$.

\section{DIMORPHOTHECA (African Daisy)}

Aurantiaca hybrida. In growth and flowers, these hybrids are like the parent; flowers equally as large but vary in color, ranging from pure white to red and various shades of yellow and orange to rich salmon shades. Pkt., $15 \mathrm{c}$.

ESCHSCHOLTZIA (California Poppy)

Dainty Queen. Delicate light pink, deepening toward the edges; center of flower delicate cream. Pkt., 10c. Golden West. Large light yellow flowers. Pkt., 10c. Mandarin. Inner side petals orange, outer side brilliant scarlet. Pkt., 10c. 
FORGET-ME-NOT (Myosotis)

Alpestris Distinction. Flowers in ten weeks after sowing. Finest for greenhouse culture. Pkt., 20c. Dissitiflora. Very free blooming and large-flowering. Compact habit. Pkt., 20c.

Palustris semperflorens. Very dwarf. Blooms from spring until autumn. A splendid outdoor sort. Succeeds best in moist or partly shady places. Pkt., $15 \mathrm{c}$.

FOXGLOVE. See Digitalis, page 9.

\section{GAILLARDIA}

Grandiflora. One of the best of our hardy herbaceous plants. Flowers crimson and gold, single, two to three inches in diameter. Pkt., 10c.; 1/4 oz., 30c. Picta Lorenziana fl. pl. These double-flowering annual gaillardias are of great merit and decided value. Bloom constantly all summer.

Finest mixed. Pkt., 10c.; 1/4 oz., 35c.

\section{GEUM (Avens)}

Atrosanguineum fl. pl. A beautiful hardy perennial, bearing profusely large double dark crimson flowers. Pkt., 10c.

Coccineum fl. pl. Mrs. Bradshaw. Flowers double, brilliant, orange-scarlet. Pkt., 15c.

Lady Stratheden. A fine variety double goldenyellow. Pkt., 25c.

\section{GLOBE AMARANTH (Gomphrena globosa)}

This is often called English Clover or Bachelor's Button.

Finest mixed. All colors. Pkt., 10c.; $1 / 4$ oz., 25c.

\section{GYPSOPHILA}

Elegans grandiflora alba. An improved largeflowering form of the annual Baby's Breath. Pure white. Pkt., 10c.; 1/4 oz., $15 \mathrm{c}$.

Elegans rosea. A very pretty annual. Light pink. Pkt., 10c.; 1/4 oz., 15c.

Paniculata (Baby's Breath). Hardy. Fine for bouquets or cutting. Pkt., $10 \mathrm{c}$.

Paniculata fl. pl. A double-flowering Baby's Breath. This variety is particularly desirable for the hardy border; also fine for cutting. Pkt., 25c.

\section{HELENIUM (Sneeze Wort)}

A very desirable hardy perennial, three to five feet; suitable for beds or shrubbery borders. Fine for cutting.

Autumnale superbum. Deep golden yellow. Pkt., $15 \mathrm{c}$.

Riverton Gem. Flowers opening old gold changing to wall flower red. Pkt., 15c.

HELICHRYSUM (Everlasting)

Monstrosum fl. pl. Finest mixed. Pkt., 10c.

HELIOTROPE. Large-flowering

Finest mixed. Dark sorts. All colors. Pkt., 15c. 
HELIANTHUS (Sunflower)

Cucumerifolius. Single miniature sunflower, two to three inches in diameter. Black center, light yellow rays. From three to four feet high, bearing a profusion of flowers all summer. Pkt., 10c.; $1 / 4$ Oz., $25 \mathrm{c}$.

Cucumerifolius hybridus fl. pl. Double-flowering hybrids. A splendid mixture of the double and semidouble varieties. Pkt., $10 \mathrm{c}$; $1 / 4$ oz., $40 \mathrm{c}$.

Cucumerifolius Stella. Single. Large flowers. Primrose yellow. Pkt., 10c.; 1/4 oz., 25c.

Globosa fistulosa fl. pl. The best of the tall-growing double-flowering sunflowers. Six feet high. Pkt., $10 \mathrm{c}$; $1 / 4$ oz., $25 \mathrm{c}$.

Red. Flowers large; single; red, shading to yellow at tips of petals. Pkt., 10c.; $1 / 4$ oz., $25 \mathrm{c}$.

Russian Mammoth. Single. Large. Sometimes grows ten to twelve feet high. Pkt., 5c.; oz., 10c.; lb., $50 \mathrm{c}$.

HELIOPSIS (Orange Sunflower)

Pitcheriana. A very desirable herbaceous plant. Grows three to four feet high. Flowers single, deep golden yellow, about two inches in diameter. Pkt., $10 \mathrm{c}$.

Scabra zinniæflora. Double golden yellow flowers, resembling the zinnia. Hardy. Pkt., 15c.

\section{HEUCHERA}

Sanguinea. A beautiful herbaceous plant, twelve to eighteen inches high, covered with a mass of small brilliant coral-colored flowers. Exquisite. Pkt., 25c.

\section{HOLLYHOCK}

Pierson's Superb Double. There is nothing showier or more beautiful than hollyhocks, and our collection will be found to be superb.

Separate colors. White, yellow, rose, scarlet, crimson. Each, pkt., 10c.; r/4 oz., 75c. Collection of five colors, one pkt. each, $40 \mathrm{c}$.

Finest mixed. All colors. Pkt., 10c.; 1/4 oz., 40c.

Alleghany, or Fringed. Single or semi-double, fringed and feathered. More brilliant than the double, having a beautiful luster, shining as if made of China silk. They are also more graceful in form.

Finest mixed. All colors. Pkt., 10c.; 1/4 oz., 40c.

IBERIS (Hardy Candytuft)

Free-flowering dwarf perennials. Blooms in early spring. Fine for rock work or herbaceous borders.

Gibraltarica. Flowers white, shaded with pink. Strong grower. Pkt., 10c.

Sempervirens. Pure white. Dwarf. The plants form a mass of white when in bloom. Pkt., 25c.

For annual varieties, see Candytuft, page 6 .

\section{IMPATIENS}

Sultani. Blooms profusely and almost continuously. Very showy for pot or garden culture. Flowers bright rose. Pkt., 25c. 


\section{KOCHIA (Summer Cypress)}

Trychophylla. Ornamental annual. Grows about three feet high, forming symmetrical cypress-like bushes. Foliage green, turning red in autumn. Pkt., 10c.; 1/4 oz., $25 \mathrm{c}$.

\section{LARKSPUR, Annual Varieties}

Very desirable. Blooms throughout the entire season. Splendid for mixed borders and fine for cutting. Emperor. Unequaled for profusion of bloom, often showing forty or fifty spikes of flowers.

Separate colors. Rose, white, azure-blue. Each, Pkt., 10c.; I/4 oz., 30c.

Finest mixed. All colors. Pkt., 10c.; I/4 oz., 25c. For perennial varieties, see Delphinium, pages 8 and 9.

\section{LATHYRUS LATIFOLIUS (Perennial Pea)}

A magnificent hardy climber. Very desirable for growing on fences, trellises, etc.

Pink Beauty. Bright rosy pink. Extra. Pkt., 20c.; I/4 oz., 60c.

White Pearl. The best. Flowers white, very large. Very strong grower. Pkt., 25c.; $1 / 4$ oz., $75 \mathrm{c}$.

Finest mixed. Pkt., 15c.; $1 / 4$ oz., $50 \mathrm{c}$.

\section{LAVENDER}

Lavandula Vera (Sweet Lavender). A sweet scented hardy perennial. Flowers blue, one and one-half feet. Pkt., 10c.; I/4 oz., 40c.

\section{LINUM (Flax)}

An erect-growing plant, with delicate flowers. Desirable for borders or rockery. Hardy. Grows about eighteen inches high.

Flavum. Yellow. Pkt., 20c.

Perenne. Bright blue. Pkt., 10c.

Perenne album. Pure white. Pkt., 10c.

\section{LOBELIA}

Cardinalis (Cardinal Flower). One of the showiest of all hardy perennials. Flowers brilliant scarlet. Extra. Pkt., 25c.

Cardinalis Queen Victoria. This fine Cardinal Flower has dark crimson leaves and brilliant scarlet flowers. Extra. Pkt., 50c.

Crystal Palace Compacta. Dark blue. Very dwarf. Finest for edging and carpet bedding. Pkt., $15 \mathrm{c}$.

Gracilis. Bright blue, trailing. For baskets or window boxes. Pkt., 10c.

\section{LUPINUS (Lupin)}

One of the beautiful hardy perennials. The stately spikes of bloom make this plant attractive.

Polyphyllus. Blue, white. Each, pkt., 10c. Rose, pkt., $15 \mathrm{c}$.

Polyphyllus Moerheimi. Rose and white. Pkt., 15c. 
LYCHNIS (Campion, or Ragged Robin)

Alpina. A dwarf variety growing six inches high. Splendid for rock gardens. Flowers rose-colored. Pkt., 25c.

Chalcedonica. Intense scarlet. Hardy. Two feet high. Pkt., 10c.

\section{MARIGOLD}

Dwarf French. One foot high. Finest mixed. Pkt., 10c.; $1 / 4$ oz., $25 \mathrm{c}$.

Eldorado. Flowers shades of yellow, enormous, measuring three and a half to four inches across. Pkt., 10c.; $1 / 4$ oz., 25c.

Tagetes signata pumila. Very dwarf and compact. Fine for edging. Covered all summer with bright yellow blossoms with reddish stripe. Pkt., 10c.; I/4 oz., 50c.

Tall African. Two feet high. Finest mixed. Pkt., 10c.; $1 / 4$ oz., $25 \mathrm{c}$.

\section{MIGNONETTE (Reseda)}

Allen's Defiance. The finest of all varieties for greenhouse culture. The most delicate of all the mammoth mignonettes. Produces large spikes of bloom twelve to fifteen inches in length. Delightfully fragrant. Pkt., 10c.; $1 / 4$ oz., 35c.; oz., $\$ 1.00$.

Machet. Dwarf and vigorous. Produces massive spikes of sweet-scented reddish flowers. Fine for either greenhouse or outdoor culture. Pkt., 10c.; $1 / 4$ oz., 35c.; oz., \$1.00.

MOONFLOWER (Ipomea grandiflora alba)

Magnificent pure white flowers five to seven inches across. A splendid quick-growing climber. Pkt., 10c.; 1/4 Oz., 25c.; Oz., $75 \mathrm{c}$.

\section{MORNING GLORY}

Brazilian. (Ipomea Setosa). Flowers three inches or more in diameter, beautiful rose color, borne very freely in large clusters from July till frost. Pkt., 10c. Common (Convolvulus major). Finest mixed. Pkt., 5c.; oz., 25c.

Imperial Japanese Giant. (Ipomea imperialis). Variegated foliage. Enormous flowers, fringed and bordered and of extraordinary beauty. This differs greatly from the common Morning Glory in shape as well as in size. Flowers are of the richest possible coloring. Pkt., 10c.; oz., 50c.

MYOSOTIS. See Forget-Me-Not, page 10.

NASTURTIUM, Dwarf or Tom Thumb Varieties

For ease of culture, duration of bloom, brilliancy of color, and general excellence, nothing excels nasturtiums. They begin to bloom almost as soon as they start to grow, and continue until hard frost.

Beauty of Malvern. Orange-scarlet. Extra. Pkt., 10c.; Oz., 30c.

Crystal Palace Gem. Sulphur, spotted maroon. Pkt., 10c.; Oz., 20c.

Empress of India. Fiery crimson, with dark foliage.

Pkt., 10c.; oz., 25c. 
NASTURTIUM-Continued.

Golden King. Rich golden yellow. Pkt., 10c.; oz., 20c.

King of Tom Thumbs. Intense scarlet flowers; bluish green foliage. Pkt., 10c.; oz., 25c.

King Theodore. Dark green foliage; almost black flowers. Pkt., 10c.; oz., 25c.

Lady Bird (Spotted King). Golden yellow, spotted rich crimson. Pkt., 10c.; oz., 25c.

Rose. Soft rose color. Pkt., 10c.; oz., 20c.

Finest mixed. All colors. Pkt., 10c.; oz., 15c.; 1/4 1b., 50c.; 1b., $\$ 1.50$.

NASTURTIUM, Lobb's Climbing

These are superior to the ordinary climbing nasturtiums. More floriferous, with smaller leaves. Splendid for training on arbors and for vases and rockwork.

Defiance. Intense scarlet flowers, with dark foliage. Pkt., 10c.; oz., 35c.

Golden Queen. Bright golden yellow. Pkt., 10c.; oz., 25c.

Margaret (Princess Victoria Louise). Light yellow, with blood-red spots and spurs. Pkt., 10c.; oz., $25 \mathrm{c}$.

Roi des Noirs. Blackish maroon. Pkt., 10c.; oz., $25 \mathrm{c}$.

Finest mixed. All colors. Pkt., 10c.; oz., 15c.; 1/4 1b., 50c.; 1b., $\$ 1.50$.

Hybrids of Mme. Gunther. Dark-leaved hybrids, very beautiful. A French strain noted for its wide range of colors. Pkt., 10c.; oz., 20c.; 1/4 1b., 60c.

\section{NICOTIANA}

Affinis. Flowers pure white, delightfully sweetscented. Blooms continuously. Grows two to three feet high. Pkt., 10c.

Sanderæ. Flowers brilliant carmine. Blooms continuously from May until frost. A lovely variety. Pkt., 10c.

ENOTHERA (Evening Primrose)

Youngii. A very showy, hardy perennial suitable for borders, beds or rockwork. Flowers large, bright lemon-yellow. Height two feet. Pkt., 15c.

PAPAVER. See Poppy, page 17.

\section{PANSY}

The seed that we offer comprises the very finest strains obtainable-very superior to the quality usually offered. No expense has been spared in obtaining the very best strains from the very best sources.

Bugnot's Superb Blotched. Flowers of enormous size; of great substance and velvety texture. Each petal has a deeply colored blotch, which runs out in delicate veinings to the edge. The shadings comprise tints of red, bronze, and brown not found in any other mixture. Pkt., 25c.; 1/8 oz., $\$ 1.00$. 
PANSY-Continued

Cassier's Giant Odier. The largest-flowered class of blotched pansies. An especially rich strain of unsurpassed quality. Very showy. Flowers are all three-blotched or five-blotched on background of very rich colors. Pkt., 25c.; I/8 oz., $\$ 1.00$.

Masterpiece (Germania). Giant curled and ruffled pansies. A fancy strain of pansies, with enormous flowers. Edges of the petals are crimped or undulating, giving the flowers almost the effect of being double. Pkt., 25c.; 1/8 oz., $\$ 1.00$.

Pierson's Perfection. This strain comprises the very richest strains of Mammoth Butterfly, Giant Ruffled and Mottled, Giant Five-spotted, Parisian, and Trimardeau, giving an unrivaled variety both in size and coloring. Pkt., 25c.; 1/8 oz., \$1.00.

Giant Emperor William. Ultramarine-blue, with violet eye. Pkt., $15 \mathrm{c}$.; $1 / 8$ oz., $50 \mathrm{c}$.

Giant Golden Queen. Pure yellow. Pkt., 15c.; $1 / 8$ oz., 75c.

Giant Lord Beaconsfield. Deep purple-violet, shading to white. Pkt., 15c.; 1/8 oz., 50c.

Giant Snowflake. (Snow Queen or Candidissima). Pure snowy white. Pkt., 15c.; 1/8 oz., 60c.

Giant White Trimardeau. White, with purple eye. Very beautiful. Pkt., 15c.; 1/8 oz., 50c.

Giant Yellow Trimardeau. Yellow, with black eye. Pkt., 15c.; I/8 oz., 60c.

Giant Trimardeau, mixed. Remarkable for the enormous size of the flowers, which are marked with three large blotches on the lower petals. Pkt.; $15 \mathrm{c}$.; I/8 oz., $45 \mathrm{c}$.

Mammoth Parisian. A strain of Trimardeau pansies, with very showy, handsome flowers, mostly white-ground and five-blotched varieties. Pkt., 15c.; r/8 oz., $60 \mathrm{c}$.

PANSIES (Tufted). See Viola, page 22.

\section{PENTSTEMON (Beard Tongue)}

Barbatus Torreyii. Hardy perennial. This variety produces spikes of brilliant scarlet flowers. Pkt., $10 \mathrm{c}$.

Large-flowering Hybrids. A hardy perennial. Bears spikes of brilliant flowers. Three to four feet high. Finest mixed. A11 colors. Pkt., 20c.

\section{PETUNIA}

A very desirable class of large-flowering Petunias, for filling vases, hanging baskets, flower boxes, also for bedding. Flowers average three inches across.

Balcony Blue. Rich indigo blue. Pkt., 25c.

Balcony Crimson. Velvety crimson. Pkt., 25c.

Balcony Rose. Brilliant rose pink. Pkt., 25c.

Balcony White. Pure white. Pkt., 25c. 
PETUNIA-Continued

Dougle-fringed. Produces a large percentage of double flowers of the largest fringed varieties in the brightest colors and tints. Pkt., 50c.

Howard's Star. Crimson-maroon, with a clearly defined five-pointed star of blush white in center. Striking and beautiful. Pkt., $15 \mathrm{c}$.

Rose of Heaven. Similar to Rosy Morn but more brilliant. Pkt., 25c.

Rosy Morn. Flowers bright rosy pink, with white throat. Compact grower. Pkt., 15c.

Ruffled Giants. Flowers very large, fluted or ruffled, and of good substance. Pkt., 50c.

Single-fringed. The finest of all single petunias. Flowers deeply fringed, highly colored, and beautifully striped. Pkt., 25c.

Snowball. A charming dwarf single petunia, covered with masses of pure white satiny flowers throughout the entire season. Pkt., 15c.

Striped and Blotched. A fine strain of the smallflowering type, beautifully striped and blotched. An infinite variety of colors. Fine for massing. Pkt., 10 c.; $1 / 4$ oz., 50 c.

\section{PHLOX DRUMMONDI GRANDIFLORA}

Alba. Pure white. Beautiful. Pkt., 10c.

Coccinea. Brilliant scarlet. Pkt., 10c.

Isabellina. Yellow. Pkt., 10c.

Leopoldii. Rose, with white eye. Pkt., 10c.

Radowitzii. Rose and white striped. Pkt., 10c.

Stellata splendens. Deep crimson, with large white eye. Pkt., 10c.

Finest Mixed. All colors. Pkt., 10c.; 1/4 oz., 50c.

PINKS. See Dianthus, page 9, and Carnation, page 6.

PLATYCODON GRANDIFLORUM (Chinese Bell

Flower). A very showy hardy perennial. Blooms the entire season, much resembling the campanula.

Separate colors. White, blue. Each, pkt., 15c.

Nana (Mariesi). Dwarf; dark blue. Splendid. Pkt., $15 \mathrm{c}$.

Nana alba. Dwarf; pure white. Pkt., 15c.

POLYANTHUS. See Primula veris, page 18.

\section{PORTULACA}

Single. Finest mixed, all colors. Pkt., 10c.; $1 / 4$ oz., 25c.; oz., 75c.

Double. Finest mixed, all colors. Pkt., 15c.; 1/4 oz., $\$ 1.00$. 
POPPY, Hardy (Papaver orientale)

These beautiful hardy poppies deserve a place in every garden. The magnificent large showy flowers produce a gorgeous effect in a hardy border or among shrubbery.

Bracteatum. A splendid variety, with very large double orange-scarlet flowers. Pkt., 15c.; 1/4 oz., 75c.

Mrs. Perry. Salmon-rose. Extra. Pkt., 25c.

Orientale. Beautiful dark brilliant scarlet. Pkt., $15 \mathrm{c}$; $1 / 4$ oz., $75 \mathrm{c}$.

Princess Victoria Louise. Bright salmon-scarlet. Superb. Pkt., 25c.

Rembrandt. Magnificent. Orange-scarlet. Pkt., $15 \mathrm{c}$.

Salmon Queen. Salmon-yellow. Fine. Pkt., 25c. Finest mixed hybrids. These hybrids contain many colors, including white, blood-red, blue-black, glowing scarlet, etc. Very fine. Pkt., $15 \mathrm{c}$.; $1 / 4$ oz., $75 \mathrm{c}$.

POPPY, Iceland (Papaver nudicaule)

These dwarf hardy perennial poppies are exceedingly showy and handsome. They grow about a foot high, and are covered with masses of bright satin-like flowers. Bloom from June to October. Very showy; also fine for cutting.

Separate colors. Bright yellow, pure white, orange. Each, pkt., 10c.

Giant mixed. All colors. Pkt., 15c.

POPPY, Annual.

Pierson's Perfection Peony-flowered. Magnificent large double flowers of the most intense color, almost as large as peonies. For brilliant, dazzling colors these poppies are equaled only by the tulip. Separate colors. White, rose, scarlet and white, fiery scarlet, light yellow. Each, pkt., 10c.

Finest mixed. All colors. Pkt., 10c.; oz., 50c.

Shirley. The finest of all single annual poppies. Flowers are immense-often measuring four to five inches across-with a beautiful satiny lustre. Plants are covered with magnificent blossoms, so varied in color that hardly any two are alike, ranging in color from the purest glistening white, through the most delicate shades of pale pink, rose and carmine, to the deepest crimson and blood-red, while many are daintily edged and striped.

Finest mixed. All colors, pkt., 10c.; $1 / 4$ oz., 25c.; oz., $75 \mathrm{c}$.

PRIMULA CHINENSIS FIMBRIATA (Fringed Chinese Primrose)

Our strain of this will be found to be a very superior quality - the very choicest obtainable from the best European sources.

Alba magnifica. Pure white, with yellow eye. One of the very finest. Pkt., 50c.

Cheswick Red. Rich deep rose. Medium-sized flower. An extra fine variety. Pkt., 50c. 


\section{PRIMULA-Continued}

Pink Beauty. Deep blush, or delicate salmon. Pkt., $50 \mathrm{c}$.

Ruby Queen. Deepest red. Pkt., 50c.

Finest mixed. All colors. Pkt., 50c.

Forbesi. (Baby Primrose). This variety produces sprays of beautiful tiny rosy-lilac flowers when the plant is only a few weeks old. Pkt., 25c.

Malacoides (The Giant Baby Primrose). This beautiful primula blooms about four months after seed is sown, forming a compact plant. Flowers light blue. Pkt., 25c.

Obconica grandiflora fimbriata. Same as obconica grandiflora except that the flowers are beautifully fringed. Pkt., 50c.

Obconica grandiflora gigantea. A giant form of obconica, producing stronger plants and larger flowers.

Rosea. Pink. Pkt., 50c.

Kermesina. Crimson. Pkt., 50c.

Finest mixed. All colors. Pkt., 50c.

Stellata. A very beautiful class of Chinese primroses. Very free-flowering, with heads much branched. Star-shaped flowers of various colors.

Finest mixed. All colors. Pkt., 50c.

\section{PRIMULA VERIS (Polyanthus)}

Gold-laced. Beautiful spring-flowering hardy primroses for garden or pot culture. Charming varieties, with small yellow-edged flowers. Hardy with protection. Pkt., 25c.

Large-flowering Hybrids. A choice strain, carefully selected for habit, color, and size of bloom. The finest strain for bedding. Pkt., 50c.

Vulgaris (English Primrose). Yellow, fragrant. Very desirable. Hardy. Pkt., 15c.

\section{PYRETHRUM}

The hardy pyrethrums are among our finest hardy herbaceous perennials.

Double Hybrids. Finest mixed. Pkt., 25c.

Single Hybrids. Finest mixed. Pkt., $15 \mathrm{c}$.

RICINUS. See Castor Oil Bean, page 7.

RUDBECKIA (Cone Flower).

Fulgida. A fine hardy perennial, producing masses of brilliant orange-yellow flowers in August and September. Pkt., 10c.

Newmani. Hardy. Flowers are large, with petals of bright orange-yellow, surrounding a large black cone. Pkt., 15c.

Purpurea (Giant Purple Cone Flower). Hardy. Large crimson-purple flowers, with dark central disc. Pkt., $15 \mathrm{c}$.

\section{SALPIGLOSSIS}

Grandiflora. Finest mixed. All colors. Pkt., 10c. 


\section{SALVIA}

Bonfire (Clara Bedman). Very compact. Semidwarf, about two feet high. Free and early-flowering. Bright scarlet. Pkt., 10c.; $1 / 4$ oz., $\$ 1.00$.

Patens. Superb rich blue flowers. A tender perennial. Fine for herbaceous borders. Pkt., 25c.

Splendens (Scarlet Sage). Bright scarlet. Pkt., 10c.; $1 / 4$ Oz., $60 \mathrm{c}$.

Splendens Zurich. An early dwarf variety. Grows about fifteen inches high, and is thickly studded with fine spikes of brilliant scarlet flowers. Pkt., 15c.

SCABIOSA (Mourning Bride, or Sweet Scabious)

Caucasica (Blue Bonnet). A very desirable hardy variety, with lilac-blue flowers. Excellent for cutting. Pkt., 25c.

Japonica. A variety from Japan. Forms bushy plants two and a half feet in height, bearing lavender blue flowers on long stems. Hardy. Pkt., 10c. Nana fl. pl. Dwarf double. Annual varieties.

Finest mixed. All colors. Pkt., 10c.

SCHIZANTHUS (Butterfly, or Fringe, Flower) Splendid for summer-blooming or for winter-flowering in pots in greenhouses. On account of their great beauty they have also been called The Poor Man's Orchid.

Hybridus grandiflorus. Very fine varieties of the richest coloring, in endless variety. Pkt., 10c.

Wisetonensis. Literally covered with magnificent small orchid-like flowers, white dotted with delicate rose, upper lip spotted darker. Pkt., 25c.

SHASTA DAISY. See page 8.

SMILAX (Myrsiphyllum asparagoides)

Pkt., 10c.; 1/4 oz., 25c.

STATICE (Sea Lavender)

Latifolia. Deep blue flowers, which last for months if cut and dried. Hardy. Pkt., 15c.

STOCKS, Ten-Week

Dresden Perpetual or Branching. Finest of all TenWeek Stocks. Bloom early, and continue in bloom for a long time. Fine for cutting and pot culture. Separate colors. White (Princess Alice), apple blossom, flesh color, rose, crimson, light blue. Each, pkt., 20c.; I/8 oz., $\$ 1.00$.

Finest mixed. All colors. Pkt., 20c.; 1/8 oz., 75c.

STOKESIA (Cornflower Aster)

Cyanea. A rare and beautiful hardy perennial. Lavender-blue cornflower-like blossoms. Blooms from July to frost. A beautiful hardy border plant. Indispensable for cutting. Pkt., 20c.; 1/4 oz., $\$ 1.00$.

Cyanea alba. White, very desirable for cutting. Pkt.,.20c.; 1/4 oz., $\$ 1.00$.

SUNFLOWER. See Helianthus, page 11. 


\section{SWEET PEAS, Spencer Varieties}

There is such an endless variety of sweet peas, many of which have been superseded by newer and much better varieties, that we have omitted all except the very best and choicest sorts.

Commander Godsall. The color is a very attractive shade of deep violet-blue. The flowers are large, of heavy substance, and attractively waved and fluted; borne in fours on long stems. Pkt., 10c.; oz., $40 \mathrm{c}$; $1 / 4$ 1b., $\$ 1.25$.

Crimson King. An exceptionally fine Sweet Pea. The flower is of immense size and artistic proportions, a rich sun-proof crimson. The standards and wings are much waved and fluted. Pkt., 10c.; oz., 40c.; $1 / 4$ 1b., $\$ 1.25$.

Fiery Cross Improved. The flowers are fiery red or rich orange-scarlet. Flowers are beautifully waved and fluted, and are borne freely on long, strong stems. Pkt., 10c.; oz., 40c.; 1/4 1b., \$1.25.

Floradale Fairy Improved. The flowers are deep cream color. The standards and wings are large, exquisitely waved, and of wax-like texture. The flowers are of the largest size and well proportioned. Pkt., 10c.; oz., 40c.; 1/4 lb., \$1.25.

George Shawyer. The flowers of this variety are large and of good form, borne four on long stems. The standards are a clear shade of bright orangesalmon and the wings tinted with rose. Pkt., 10c.; oz., 40c.; $1 / 4$ lb., $\$ 1.25$.

Hawlmark Salmon Pink. The blooms are very large, rich deep pink with a salmon and orange tint in the standard. It is a strong grower and free bloomer. The handsome waved blooms are artistically arranged in fours on long strong stems. Pkt., 10c.; oz., 50c.; 1/4 1b., $\$ 1.50$.

Hercules. A magnificent soft rose-pink flower, of large size and substance. Pkt., 10c.; Oz., 40c.; 1/4 1b., $\$ 1.25$.

King White Improved. A very fine white sweet pea. The flowers are of the Spencer type, of gigantic size, pure white, of good substance, produced on long, strong stems, usually four flowers to the spray. Pkt., 10c.; Oz., 40c.; 1/4 lb., \$1.25.

Mrs. Tom Jones. The flowers of this variety are a bright Delphinium blue, very large, beautifully waved and of great substance. Usually borne four on long stems. Pkt., 10c.; oz., 40c.; 1/4 1b., \$1.25.

Orchid Improved. The flowers are larger and decidedly more waved and crimped on the edges than the variety Orchid. The color is a clear Cattylealavender pink. Pkt., 10c.; oz., 40c.; 1/4 1b., \$1.25. 
SWEET PEAS, Spencer Varieties-Continued

Picture. The flowers are of immense size and beautifully formed. The color is a blend of cream and pink tones, with a deeper flush of pink on the wings. It is a strong grower and free bloomer, bearing four artistic blooms on long strong stems. Pkt., 10c.; oz., 40 c.; $1 / 4$ lb., $\$ 1.25$.

Royal Scot. A wonderful brilliant scarlet or deep cerise sweet pea. The blooms are not only very large, but well formed and gracefully waved and fluted. It is a strong grower and free bloomer. Pkt., 10c.; oz., 40c.; 1/4 1b., $\$ 1.25$.

Spencer Varieties Mixed. A fine assortment of Giant Waved Spencer varieties (often called orchidflowered) in fine mixture. Pkt., 10c.; oz., 25c.; $1 / 4$ 1b., 75c.; 1b., $\$ 2.50$.

SWEET PEAS, Early or Winter-flowering Varieties. Choice varieties for forcing under glass or can be used for outdoor planting.

Blue Bird. A charming shade of blue. Pkt., 15c.; oz., $\$ 1.00$.

Columbia. Blanche Ferry color. Considered by many to be the best pink and white variety. Pkt., $15 \mathrm{c}$; oz., $\$ 1.00$.

Glitters. Flowers orange-scarlet; a strong vigorous grower. Pkt., 15c.; oz., $\$ 1.00$.

Jeanne Mamitsch. A magnificent variety. The flowers are a bright rose pink. Pkt., 25c.; I/2 oz., $\$ 1.25$; oż., $\$ 2.00$.

Lavender King. A fine lavender sort. Pkt., 15c.; oz., $\$ 1.00$.

Mrs. Calvin Coolidge. Flowers large brilliant salmon pink, suffused with bronzy orange in the standard. The wings show a delicate rose cast blending harmoniously with the standard, producing a beautiful iridescent salmon-pink color. Pkt., $25 \mathrm{c}$.; $1 / 2 \mathrm{oz}$, $\$ 1.25 ;$ oz., $\$ 2.00$.

Mrs. Kerr. The best early-flowering salmon. The flowers are of immense size and exquisite shape. Pkt., 20c.; oz., \$1.25.

Rose Queen. An exceptionally fine rose-pink variety. Pkt., 15c.; oz., $\$ 1.00$.

Snowstorm Improved. The flowers are immense in size. The best early-flowering white. Pkt., 15c.; oz., $\$ 1.00$.

Zvolanek's Rose. Large rose-colored blooms. Pkt., $15 \mathrm{c}$; oz., $\$ 1.00$.

SWEET PEAS, Perennial. See Lathyrus latifolius. page 12 . 
SWEET WILLIAM (Dianthus barbatus)

These showy, old-fashioned, hardy garden plants are among the most desirable for beds or hardy borders.

Diadem. Deep rich crimson, with large pure white eye. Pkt., 10c.; 1/4 oz., 25c.

Double. Finest mixed, all colors. Pkt., 10c.; 1/4 oz., 35 c.

Holborn Glory. Single, with extra large flowers. The finest shades of colors, beautiful eyes and fine margins. An endless variety. Pkt., $15 \mathrm{c}$; $1 / 4$ oz., 50c. Newport Pink. A very fine variety originating at Newport, R. I. Flowers salmon pink. Pkt., 15c.; I/4 Oz., 75c.

Pink Beauty. Flowers large; fine, deep pink. Pkt., $15 \mathrm{c}$; $1 / 4$ oz., $50 \mathrm{c}$.

Scarlet Beauty. Rich deep scarlet. Pkt., 15c.; 1/4 oz., $50 \mathrm{c}$.

White. Flowers large, white. Pkt., 10c.; 1/4 oz., 25c.

\section{TORENIA}

Fournieri. Sky-blue, with three large blue spots and a yellow throat. Pkt., 15c.

TROP 开OLUM. See Nasturtium, pages 13 and 14 .

VERBENA, Mammoth-flowered.

Largest-flowered varieties, very finest strain.

Separate colors. Scarlet, pink, purple, white. Each, pkt., 10c.

Finest mixed. All colors. Pkt., 10c.; 1/8 oz., 50c.

VINCA (Madagascar Periwinkle)

Fine for summer bedding. Constantly in bloom.

Alba pura. Pure white. Pkt., 10c.

Rosea. Bright rose, dark eye. Pkt., 10c.

Rosea alba. White, rose center. Pkt., 10c.

VIOLA CORNUTA (Tufted Pansies)

Biue Gem (Jersey Gem). A wonderful new Viola. This variety produces almost continuously from May until September, long stemmed violet-blue flowers, very fragrant. It is a strong grower of compact habit and when in bloom is a mass of color. Pkt., 25c.

Blue Perfection. Deep purplish blue. Pkt., 15c.

Lutea Grandiflora (Splendens). Rich golden yellow. Pkt., 15c.

WAHLENBERGIA. See Playtcodon, page 16.

ZINNIA, Giant or Mammoth-flowered

We offer a very superior strain of this most popular flower. The flowers are perfectly formed. Very large, often measuring five to six inches across.

Separate colors. White, pink, golden yellow, scarlet, crimson, salmon. Each, pkt., $15 \mathrm{c}$; $1 / 4 \mathrm{oz}$., $50 \mathrm{c}$.

Finest mixed. All colors. Pkt., $15 \mathrm{c}$.; $1 / 4$ oz., $40 \mathrm{c}$. 


\section{VEGETABLE SEEDS}

Our seeds are tested seeds of the very best quality obtainable, and our prices are fixed at the very lowest rates consistent with high quality. While we exercise the greatest care to have all our seeds pure and reliable, we give no warranty, expressed or implied, and will in no way be responsible for the crop. If purchaser does not accept our goods on these conditions, goods must be returned at once.

\section{ASPARAGUS}

Palmetto. The best asparagus. Earlier and larger than Colossal. Pkt., 10c.; oz., 20c.; 1/4 1b., 50c.

For Asparagus Roots, see page 34.

BEANS, BUSH-Wax varieties

Burpee's Kidney Wax. Broad pods, stringless. Excellent. 1/4 1b., 15c.; 1b., 50c.; 2 lbs., $95 \mathrm{c}$.

Currie's Rust-Proof Wax. Pods long and straight. Prolific. I/4 1b., 15c.; 1b., 45c.; 2 1b., 85c.

Improved Golden Wax. Improved strain of Golden Wax. I/4 1b., 15c.; 1b., 45c.; 2 lbs., 85c.

Refugee Wax. Very prolific. Long, round pods. I/4 1b., 15c.; 1b., 45c.; 2 lbs., 85c.

BEANS, BUSH-Green-podded Sorts

Bountiful. Very early; prolific. Pods long, green, flat, tender, and stringless. $1 / 4$ 1b., 15c.; 1b., 50c.; 2 lbs., 95c.

Burpee's Improved Bush Lima. Pods and beans larger than Burpee's Bush Lima. 1/4 1b., 15c.; 1b., 50c.; 2 1bs., 95c.

Dreer's Bush Lima. Similar to Dreer's Pole Lima, but dwarf. 1/4 1b., 15c.; 1b., 50c.; 2 1bs., 95c.

Improved Early Valentine. Very early. Round pods. I/4 1b., 15c.; 1b., 45c.; 2 lbs., 85c.

Long Yellow Six Weeks. Pods flat and green. $1 / 4$ lb., 15c.; 1b., 45c.; 2 lbs., $85 \mathrm{c}$.

Refugee, or Thousand-to-One. Round pods. Very productive and tender. Medium early. 1/4 1b., 15c.; lb., 45c.; 2 lbs., 85c.

Refugee, Extra Early. Similar to Refugee, or Thousand-to-One, but fully two weeks earlier. $1 / 4$ 1b., 15c.; 1b., 45c.; 2 1bs., 85c.

Stringless Green Pod. Superior to any of the greenpodded sorts. $1 / 4$ lb., 15c.; 1b., 50c.; 2 lbs., 95c. 


\section{BEANS, POLE}

Dreer's Improved Lima. Pods thicker and shorter than large Lima. I/4 1b., 15c.; 1b., 50c.; 2 1bs., 95c.

Extra Early Jersey Lima. One of the earliest Limas. I/4 1b., 15c.; 1b., 50c.; 2 1bs., 95c.

Kentucky Wonder. Fine green-podded sort. Early stringless. $1 / 4$ 1b., 15c.; 1b., 45c.; 2 1bs., 85c.

King of the Garden Lima. Excellent. Large pod and bean. I/4 1b., 15c.; 1b., 50c.; 2 1bs., 95c.

Large White Lima. Selected stock. Best for general crop. $1 / 4$ 1b., 15c.; 1b., 50c.; 2 lbs., 95c.

Scarlet Runner. Very ornamental. Scarlet blossoms. I/4 1b., 15c.; 1b., 50c.; 2 lbs., 95c.

BEET-for Table

Columbia. Round and smooth. Flesh blood-red. Extra early. Pkt., 10c.; Oz., 20c.; 1/4 1b., 50c.; 1b., $\$ 1.50$.

Crimson Globe. Globe-shaped. Deep purple flesh. Pkt., 10c.; Oz., 20c.; 1/4 1b., 60c.; 1b., \$1.75.

Crosby's Egyptian. Better than Egyptian. Extra early; round dark red. Pkt., 10c.; oz., 20c.; 1/4 lb., 60c.; 1b., \$1.75.

Detroit Dark Red. Round; medium size; globeshaped. Skin dark red; flesh solid, vermilion-red. Pkt., 10c.; oz., 20c.; I/4 1b., 60c.; 1b., \$2.00.

Dewing's Improved Blood Turnip. Deep bloodred. A favorite market sort. Pkt., 10c.; oz., 20c.; $1 / 4$ lb., 50c.; 1b., $\$ 1.50$.

Early Model. Flesh and skin deep crimson. Perfect globe-shaped; superior quality. Very early. Pkt., 10c.; oz., 20c.; 1/4 1b., 60c.; 1b., $\$ 2.00$.

Eclipse. Very early and sweet. Pkt., 10c.; oz., 20c.; I/4 1b., 50c.; lb., \$1.50.

Edmand's Turnip. Dark red. A good sort for market garden. Pkt., 10c.; oz., 20c.; 1/4 1b., 50c.; 1b., $\$ 1.50$.

Long Smooth Blood. Long, smooth, red. Late. Pkt., 10c.; Oz., 20c.; I/4 1b., 50c.; 1b., $\$ 1.50$.

Swiss Chard, or Silver Beet. Grown for the leaves. Used as spinach. Pkt., 10c.; oz., 20c.; I/4 1b., 50c.; 1b., $\$ 1.50$.

BEET-For Feeding Stock

Golden Tankard Mangel Wurzel. Bright yellow. Oz., 10c.; I/4 1b., 35c.; lb., \$1.00.

Lane's Imperial White Sugar. White flesh. Oz., 10c.; 1/4 1b., 35c.; 1b., \$1.00.

Mammoth Long Red Mangel Wurzel. Very large and productive. Oz., 10c.; 1/4 1b., 35c.; 1b., \$1.00. 


\section{BRUSSELS SPROUTS}

Improved Dwarf. Pkt., 10c.; oz., 75c.; I/4 1b., \$2.25.

CABBAGE-Early and Second Early Varieties

All Seasons. Large. Nearly as early as Early Summer. Pkt., 10c.; oz., 60c.; 1/4 1b., \$2.00.

Copenhagen Market. A fine early large roundheaded variety. Heads very solid, uniform in size. Pkt., 15c.; oz., \$1.00; 1/4 1b., \$3.00.

Early Jersey Wakefield. Very early. Cone-shaped. Pkt., 15c.; oz., $\$ 1.00$; 1/4 1b., $\$ 3.00$.

Henderson's Early Summer. Large, round and compact. Pkt., 10c.; oz., 75c.; 1/4 1b., \$2.25.

Succession. Large. Ten days later than Early Summer. Pkt., 10c.; oz., 75c.; 1/4 1b., \$2.25.

CABBAGE_Late or Winter Varieties

Autumn King. Finest late cabbage. Large solid heads. Pkt., 10c.; oz., 75 c.; $1 / 4$ 1b., $\$ 2.25$.

Danish Ball Head. One of the best winter sorts. Heads round and solid. Pkt., 10c.; oz., 75c.; 1/4 lb., $\$ 2.50$.

Mammoth Rock-Red. The largest and best red cabbage. Pkt., 10c.; oz., 75c.; 1/4 1b., \$2.50.

Perfection Drumhead Savoy. The best of the Savoys. Pkt., 10c.; oz., 75c.; 1/4 1b., \$2.25.

Premium Flat Dutch. The standard sôrt for fall and winter. Pkt., 10c.; oz., 60c.; $1 / 4$ lb., $\$ 2.00$.

Volga. The nearest approach to perfection of any cabbage. Remarkable for uniformity and solidity. The quickest-growing late cabbage, maturing heads fully two weeks earlier than any other late kind. Quality exceedingly fine, firm, tender, and white. Pkt., 15c.; oz., $\$ 1.00 ; 1 / 4$ lb., $\$ 3.00$.

\section{CARROT}

Chantenay Half Long. Stump-rooted. Medium early, half long. Flesh deep orange-red. Pkt., 10c.; oz., 20c.; 1/4 1b., 60c.; 1b., \$2.00.

Danvers Half Long. Heavy cropper. Orange. Roots eight to ten inches long. Pkt., 10c.; oz., 20c.; 1/4 1b., 60c.; 1b., $\$ 2.00$.

Early French Forcing. Small round root. The earliest sort. Pkt., 10c.; oz., 25c.; 1/4 1b., 75c.; 1b., $\$ 2.50$.

Early Short Horn. A quick-growing sort. Roots six to eight inches long. Pkt., 10c.; oz., 25c.; 1/4 1b., 75 c.; 1b., $\$ 2.50$.

Long Orange Improved. Extensively grown for winter use. Pkt., 10c.; 0z., 20c.; 1/4 1b., 60c.; 1b., $\$ 1.75$. 


\section{CAULIFLOWER}

Extra Early Dwarf Erfurt. A fine early variety. Pkt., 25c.; 1/4 oz., \$1.25; oz., \$3.50.

Half Early Paris, or Nonpareil. Late, for fall use. Pkt., 10c.; I/4 oz., 50c.; oz., \$1.50.

Henderson's Early Snowball. The earliest and finest of all cauliflowers for garden culture or forcing. Snow-white heads, tender, of delicious flavor. Pkt., 25 c.; $1 / 4$ oz., $\$ 1.25 ;$ oz., $\$ 4.00$.

\section{CELERY}

Apple-shaped Celeriac, or Turnip-rooted Celery. Pkt., 10c.; Oz., 75c.; 1/4 1b., \$2.25.

Easy Blanching. A splendid Celery for early fall or winter use. It blanches easily; is a vigorous grower; and is a fine keeper. Pkt., 15c.; oz., \$1.00; I/4 1b., $\$ 3.50$.

Giant Pascal. Stalks large, solid and crisp. Late, fine for winter use. Pkt., 10c.; oz., 75c.; 1/4 lb., $\$ 2.25$.

Golden Self-blanching. French-grown. Very early. Compact. Delicious. Pkt., 15c.; oz., $\$ 1.00$; 1/4 lb., $\$ 3.50$.

White Plume Improved. The best for early fall use. Pkt., 10c.; Oz., 75c.; 1/4 1b., \$2.25.

Winter Queen. An excellent celery. Fine for winter use. Stalks heavy, solid, with a large heart. Pkt., 10c.; oz., 75c.; 1/4 1b., \$2.25.

\section{CHICORY}

Witloof (French Endive). One of the best winter salads. Pkt., 10c.; oz., 50c.; 1/4 1b., $\$ 1.50$.

\section{CORN, SWEET}

Bantam Evergreen. This variety is a cross between Golden Bantam and Stowell's Evergreen. Medium early. Large ears. Rich golden yellow. Very sweet. 5/4 1b., 15c.; 1b., 50c.; 2 1bs., 95c.; 10 lbs., $\$ 4.50$.

Country Gentleman. Distinct. Small cob with deep pearly white kernels. $\mathrm{I} / 4$ 1b., 15c.; 1b., 45c.; 2 lbs., 85 c.; 10 lbs., $\$ 4.00$.

Early Champion. Early. Large ears. I/4 1b., 15c.; 1b., 45c.; 2 lbs., 85c.; 10 lbs., $\$ 4.00$.

Early Mayflower. This variety is fully a week earlier than White Cory. The ears are long and very sweet and tender. $1 / 4$ 1b., 15c.; 1b., 45c.; 2 lbs., $85 \mathrm{c}$; 10 1bs., $\$ 4.00$.

Golden Bantam. Early. Dwarf. Small ears. Yellow kernels. Very sweet. I/4 1b., 15c.; 1b., 45c.; 2 lbs., 85 c.; 10 lbs., $\$ 4.00$.

Howling Mob. An early large-eared sort, maturing three to five days later than the extra early Cory. Very sweet. $1 / 4$ 1b., 15c.; 1b., 45c.; 2 lbs., 85c.; 10 1bs., $\$ 4.00$. 
CORN, SWEET-Continued

Mammoth Sugar. Late. Good for main crop. $1 / 4$ 1b., 15c.; 1b., 45c.; 2 1bs., 85c.; 10 lbs., \$4.00.

Potter's Excelsior, or Squantum Sugar. Second early. Delicious. 1/4 1b., 15c.; 1b., 45c.; 2 1bs., 85c.; 10 lbs., $\$ 4.00$.

Stowell's Evergreen. Late. A favorite sort. 1/4 1b., 15c.; 1b., 45c.; 2 lbs., 85c.; 10 lbs., $\$ 4.00$.

\section{CRESS}

Extra Curled (Pepper Grass). Pkt., 10c.; oz., 15c.; I/4 1b., 45c.; 1b., \$1.25.

Water. Pkt., 10c.; oz., $75 \mathrm{c}$.

\section{CUCUMBER}

Cool and Crisp. Early. Good table sort. Pkt., 10c.; oz., 20c.; 1/4 1b., 60c.; 1b., \$1.75.

Green Prolific Pickling. The best sort for pickling. Pkt., 10c.; oz., 20c.; 1/4 1b., 50c.; 1b., \$1.75.

Japanese Climbing. Fruit long, dark green. Flesh white. Pkt., 10c.; oz., 25c.; 1/4 1b., 75c.; 1b., \$2.25.

White Spine Improved. The best market sort. Pkt., 10c.; oz., 20c.; 1/4 1b., 60c.; 1b., \$1.75.

CUCUMBER, English Frame

Telegraph. For forcing. Pkt., 10 seeds, 25c.

\section{EGG PLANT}

Black Beauty. Early. Large, spineless. Skin rich purplish black. Pkt., 10c.; oz., 90c.

New York Improved Spineless. Very large. Standard sort. Pkt., 15c.; oz., \$1.00.

\section{ENDIVE}

Broad-leaved Batavian. Pkt., 10c.; oz., 25c.; 1/4 lb., $75 \mathrm{c}$.

Green Curled. Pkt., 10c.; oz., 25c.; 1/4 1b., $75 \mathrm{c}$.

White Curled. Pkt., 10c.; oz., 25c.; I/4 lb., $75 \mathrm{c}$.

\section{HIERBS}

Fennel, Lavender, Marjoram, Rosemary, Sage, Sweet Basil, Summer Savory, Thyme. Pkt., 10c. each.

\section{KALE, or BORECOLE}

Dwarf Green Curled Siberian (German Greens or Sprouts). Pkt., 10c.; oz., 25c.; 1/4 lb., 75c.

Tall Green Curled Scotch. Pkt., 10c.; oz., 25c.; 1/4 1b., $75 \mathrm{c}$.

\section{KOHL-RABI}

Early White Vienna. Pkt., 10c.; oz., 50c.; 1/4 lb., $\$ 1.50$. 


\section{LEEK}

Large American Flag. Pkt., 10c.; oz., 45c.; I/4 1b., $\$ 1.25$.

\section{LETTUCE}

Big Boston. Very large solid heads. Good for forcing or garden use. Pkt., 10c.; oz., 25c.; I/4 1b., $75 \mathrm{c}$.; $1 \mathrm{~b} ., \$ 2.50$.

Black-seeded Simpson. Very tender, forming a large compact bunch. Pkt., 10c.; oz., 25c.; 1/4 1b., 75c.; 1b., $\$ 2.50$.

Deacon. A fine variety. Forms large solid heads, light green in color. Very crisp and tender. One of the best for summer use. Pkt., 10c.; oz., 25c.; 1/4 1b., 1b., 75c.; 1b., $\$ 2.50$.

Grand Rapids Forcing. Large and tender. One of the best for forcing. Pkt., 10c.; oz., 25c.; $1 / 4 \mathrm{lb}$., $75 \mathrm{c}$; $1 \mathrm{~b} ., \$ 2.50$.

Hanson Improved. Large solid heads. Good for mid.summer. Pkt., 10c.; oz., 25c.; 1/4 1b., 75c.; 1b., $\$ 2.50$.

May King. A quick-growing variety. Heads large, round, and solid. Outer leaves light green, slightly tinged with brown; inner leaves rich golden yellow. Of rich flavor. Excellent for forcing. Pkt., 10c.; oz., 25c.; 1/4 1b., 75c.; 1b., $\$ 2.50$.

Mignonette. Outer leaves russet colored. Compact, solid heads, creamy white. Pkt., 10c.; oz., 35c.; 1/4 1b., $\$ 1.00 ; 1 \mathrm{~b} ., \$ 3.00$.

New York or Wonderful. Heads nearly eighteen inches in diameter, weighing nearly four pounds. Nearly as large as a summer cabbage. Pkt., 10c.; oz., 45c.; 1/4 1b., $\$ 1.25 ; 1$ b., $\$ 4.00$.

Salamander. Fine compact heads. Resists heat well. Pkt., 10c.; oz., 25c.; 1/4 1b., 75c.; 1b., $\$ 2.50$.

Trainon Self-closing Cos. The best Cos lettuce. Pkt., 10c.; oz., 25c.; I/4 1b., 75c.; 1b., $\$ 2.50$.

\section{MELON, MUSK}

Burrell's Gem. A grand melon. Oval shape, dark green skin, thin rind, and reddish orange flesh. Very thick, fine grained, and spicy. Excellent. Pkt., 10c.; oz., 25c.; 1/4 1b., 75c.; 1b., $\$ 2.25$.

Emerald Gem. Medium size. Sweet and delicious. Pkt., 10c.; oz., 25c.; I/4 1b., 75c.; 1b., $\$ 2.25$.

Extra Early Improved Hackensack. Large; deeply netted. Pkt., 10c.; oz., 25c.; 1/4 1b., 75c.; 1b., $\$ 2.25$.

Montreal Market. Very large; deeply netted. Thick green flesh. Pkt., 10c.; oz., 25c.; 1/4 1b., 75c.; 1b., $\$ 2.50$.

Osage. Larger than Emerald Gem. Salmon flesh. Pkt., 10c.; oz., 25c.; 1/4 1b., 75c.; 1b., $\$ 2.50$. 


\section{MELON, WATER}

Citron. For preserving only. Pkt., 10c.; oz., 20c.; I/4 1b., 50c.; 1b., $\$ 1.50$.

Cole's Early. A fine early variety, medium size, nearly round; rind dark green striped a lighter shade; flesh deep pink and excellent quality. Pkt., 10c.; Oz., 20c.; 1/4 1b., 50c.; 1b., \$1.50.

Fordhook Early. Early; nearly round. Skin green; flesh bright red. Pkt., 10c.; oz., 20c.; 1/4 1b., 50c.; 1b., $\$ 1.50$.

Halbert Honey. The finest of all for the home garden. Flesh crimson; luscious flavor. Pkt., 10c.; oz., 20c.; 1/4 1b., 60c.; 1b., \$1.75.

Kleckley's Sweets. Medium to large size. Medium early, very sweet; oblong in form tapering towards the stem end; rind very dark green; flesh bright red. Pkt., 10c.; oz., 20c.; 1/4 1b., 60c.; 1b., \$1.75.

Tom Watson. Long oval shape, thin but tough rind, flesh bright scarlet. Pkt., 10c.; oz., 20c.; 1/4 1b., 50c.; 1b., $\$ 1.50$.

\section{MUSHROOM SPAWN}

Bricks. American. Pure culture. Bricks of about $1 \mathrm{I} / 4$ lbs., $45 \mathrm{c}$. each; 10 bricks, $\$ 4.00$.

\section{OKRA}

White Velvet. Large pods. Round and smooth. Ivory-white. Pkt., 10c.; oz., 20c.; I/4 1b., 50c.; 1b., $\$ 1.50$.

\section{ONION}

Ailsa Craig. Finest of all onions for exhibition purposes. It can be grown to immense size and weight. Fine globular form, pale yellow skin. Imported seed. Pkt., 15c.; oz., \$1.00; 1/4 1b., \$3.00.

Barletta. Earliest onion. Good for pickling or bunching. Pkt., 10c.; oz., 60c.; r/4 1b., \$2.00.

Mammoth Silver King. Enormous. Flat; skin and flesh silvery white. Pkt., 10c.; oz., 50c.; I/4 1b., \$1.50.

Prize Taker. Large; mild; yellow skin. Pkt., 10c.; oz., 50c.; I/4 1b., $\$ 1.50$.

Southport Red Globe. Large; red; globe-shaped. Good keeper. Pkt., 10c.; oz., 50c.; I/4 1b., \$1.50.

Southport White Globe. Globe-shaped. Firm. Good keeper. Pkt.; 10c.; oz., 60c.; 1/4 1b., \$2.00.

Wethersfield. Large; red. Excellent. Pkt., 10c.; oz., 50 c.; $1 / 4$ lb., $\$ 1.50$.

White Portugal, or Silverskin. A large flat white onion. Pkt., 10c.; oz., 60c.; 1/4 1b., \$1.75.

Yellow Globe Danvers. The true yellow Danvers. Pkt., 10c.; oz., 50c.; 1/4 lb., \$1.50. 


\section{ONION SETS}

White. Qt., 45c.; 4 qts., $\$ 1.70$.

Yellow. Qt., 40c.; 4 qts., $\$ 1.50$.

\section{PARSLEY}

Champion Moss Curled. A standard variety. Pkt., 10c.; oz., 20c.; 1/4 1b., 50c.; 1b., $\$ 1.50$.

Emerald. Very curly; bright green. Pkt., 10c.; oz., 20c.; $1 / 4$ 1b., 50c.; 1b., $\$ 1.50$.

\section{PARSNIP}

Long, Smooth, or Hollow Crown. Pkt., 10c.; oz., 20c.; 1 $1 / 4$ 1b., 50c.; 1b., $\$ 1.50$.

PEAS-Earliest Varieties

Alaska. Earlier than the extra early varieties. Seed green. Height $2 \mathrm{t} / 2$ feet. $1 / 4 \mathrm{lb}$., 15c.; 1b., 40c.; $2 \mathrm{lbs}$., $75 \mathrm{c}$; 10 1bs., $\$ 3.50$.

American Wonder. A favorite early dwarf wrinkled sort. Height 1 foot. $1 / 4$ lb., 15c.; lb., 45c.; 2 lbs., 85c.; 10 lbs., $\$ 4.00$.

Gradus (Prosperity). Earliest of the large wrinkled sorts. Height 3 feet. $1 / 4$ 1b., 15c.; 1b., 50c.; 2 lbs., 95 c.; 10 lbs., $\$ 4.50$.

Laxtonian. A grand dvarf wrinkled pea, with enormous pods, which are filled with large luscious peas of the finest quality. Height, $1 \mathrm{t} / 2$ feet. $1 / 4 \mathrm{lb}$., $15 \mathrm{c}$.; lb., 50c.; 2 lbs., 95c.; 10 lbs., $\$ 4.50$.

Little Marvel. This variety is fully as early as American Wonder or Nott's Excelsior, but has larger pods and is a heavier cropper. Height $11 / 2$ feet. $1 / 4$ 1b., 15c.; 1b., 50c.; 2 lbs., 95 c.; 10 lbs., $\$ 4.50$.

Nott's Excelsior. Early dwarf sort. Larger than American Wonder. Height $11 / 4$ feet. $1 / 4$ lb., 15c.; 1b., 45c.; 2 lbs., 85c.; 10 lbs., $\$ 4.00$.

Sutton's Excelsior. An early dwarf variety. Pods are large and broad, filled with large peas of the finest flavor. Height $11 / 4$ feet. $1 / 4$ 1b., $15 \mathrm{c}$.; 1b., $45 \mathrm{c}$.; 2 lbs., 85c.; 10 lbs., $\$ 4.00$.

PEAS-Second Early Varieties

American Champion (Duke of Albany). Immense pod; peas the size of Telephone. Height 4 feet. $1 / 4$ lb., 15c.; 1b., 45c.; 2 lbs., 85c.; 10 lbs., $\$ 4.00$.

Dwarf Telephone (Carter's Daisy). Excellent. Large, well-filled pods, peas of fine flavor. Height $11 / 2$ feet. $1 / 4$ lb., 15c.; lb., 45c.; 2 lbs., 85 c.; 10 lbs., $\$ 4.00$.

PEAS-For Late or Main Crop

Champion of England. The best and most popular pea grown. Height 5 feet. $1 / 4$ 1b., 15c.; 1b., 45c.; 2 lbs., 85c.; 10 lbs., $\$ 4.00$. 
Mammoth Melting Sugar. Edible pod. Pods and peas of the finest quality. Height 4 feet. $1 / 4$ lb., 15c.; 1b., 50c.; 2 1bs., 95c.

Stratagem Improved. Best intermediate or late sort. Height 21/4 feet. 1/4 1b., 15c.; 1b., 45c.; 2 1bs., 85c.; 10 lbs., $\$ 4.00$.

Telephone. Very productive. Finest quality; excellent flavor. Height 4 feet. $1 / 4$ 1b., $15 \mathrm{c}$; 1 1b., $45 \mathrm{c}$.; 2 lbs.; 85c.; 10 lbs., $\$ 4.00$.

\section{PEPPER}

Baby Bell. A fine dwarf variety. Fruit is of medium size; brilliant waxy scarlet; sweet, mild flavor. A very heavy yielder. Pkt., $15 \mathrm{c}$. ; oz., $\$ 1.00$.

Chinese Giant. The best and largest of all the peppers. Pkt., 20c.; oz., \$1.25.

Large Bell, or Bull Nose. Large; bright red. Largely used for pickling. Pkt., 10c.; oz., 80c.

Ruby King. Large; bright red; mild. Extra. Pkt., 10c.; oz., 80c.

\section{PUMPKIN}

Cheese. Fine for family use. Large, flat, round. Creamy yellow skin; thick orange flesh of fine quality. A good keeper. Pkt., 10c.; oz., 20c.; 1/4 1b., 50c.; 1b., \$1.50.

Connecticut Field. Usually grown for feeding stock. Pkt., 10c.; oz., 20c.; 1/4 1b., 50c.; 1b., \$1.50.

Jumbo, or King of the Mammoths. The largest variety grown. Pkt., 10c.; oz., $25 \mathrm{c}$.; $1 / 4$ 1b., $75 \mathrm{c}$.; 1b., $\$ 2.25$.

Sugar. A small round fine-grained variety. Skin deep orange-yellow, flesh sweet. One of the best for pies. Pkt., 10c.; oz., 20c.; 1/4 1b., 60c.; 1b., $\$ 2.00$.

RADISH-Summer and Forcing Varieties

Crimson Giant. About double the size of Scarlet Globe. Very crisp and tender. Fine for open ground or forcing under glass. Pkt., 10c.; oz., 20c.; $1 / 4$ 1b., 60c.; 1b., \$1.75.

French Breakfast. Olive shaped, white tipped. Fine for forcing. Pkt., 10c.; oz., 20c.; $1 / 4$ 1b., 50c.; 1b., $\$ 1.50$.

Icicle. A long, white Radish. Can be used for open ground or forcing frames. Pkt., 10c.; oz., 20c.; $1 / 4$ lb., 50c.; 1b., $\$ 1.50$.

Non Plus Ultra. Improved Early Round Dark Red. Fine for forcing or open ground. Pkt., 10c.; oz., 20c.; I/4 1b., 50c.; 1b., $\$ 1.50$.

Scarlet Globe. Fine for open ground; also for forcing. Pkt., 10c.; oz., 20c.; 1/4 1b., 50c.; 1b., \$1.50.

White Strasburg. A fine large solid white summer radish. Roots oblong. Mild flavor. Pkt., 10c.; oz., 20c.; I $/ 4$ 1b., 50c.; 1b., $\$ 1.50$. 
RADISH-Summer and Forcing Varieties-Continued White Tipped Scarlet Turnip. Pkt., 10c.; oz., 20c.; I/4 1b., 50c.; 1b., \$1.50.

White Turnip. Pkt., 10c.; oz., 20c.; I/4 1b., 50c.; lb., $\$ 1.50$.

RADISH-Fall and Winter Varieties

California Mammoth White Winter. A large white winter sort. Pkt., 10c.; oz., 20c.; I/4 lb., 50c.; 1b., $\$ 1.50$.

Rose China Winter. Rose colored skin.; white flesh. Pkt., 10c.; Oz., 20c.; I/4 1b., 50c.; 1b., \$1.50.

Round Black Spanish. Globe-shaped; white flesh. Pkt., 10c.; oz., 20c.; I/4 1b., 50c.; 1b., $\$ 1.50$.

\section{SALSIFY}

Mammoth Sandwich Island. Large. Superior to Long White French. Pkt., 10c.; Oz., 50c.; I/4 1b., $\$ 1.50$.

\section{SPINACH}

Improved Thick-leaved. Early. Fine for spring or fall use. Pkt., 10c.; oz., 15c.; 1/4 1b., 25c.; 1b., 75c.

Long Standing. Best for early spring sowing. Pkt., 10c.; oz., 15c.; $1 / 4$ 1b., 25c.; 1b., 75c.

New Zealand. Best for midsummer. Should be transplanted in hills. Pkt., 10c.; oz., 20c.; I/4 1b., 50c.; 1b., \$1.50.

Savoy-leaved. Leaves curled like Savoy cabbage. Very hardy. Pkt., 10c.; oz., 15c.; I/4 1b., 25c.; lb., $75 \mathrm{c}$.

Victoria. Heavy, broad, crumpled, dark green leaves. Stands the summer heat well. Pkt., 10c.; oz., 15c.; I/4 1b., 25c.; 1b., 75c.

\section{SQUASH}

Boston Marrow. Fine for fall. Oval; bright orange; yellow flesh. Pkt., 10c.; oz., 20c.; 1/4 lb., 60 c.; 1b., $\$ 2.00$.

Giant Summer Crookneck. Double the size of the common Crookneck. Pkt., 10c.; oz., 25c.; 1/4 1b., $75 \mathrm{c}$; $1 \mathrm{~b} ., \$ 2.25$.

Hubbard. The standard winter sort. Pkt., 10c.; oz., 25 c.; I/4 1b., 75c.; 1b., $\$ 2.25$.

Warted Hubbard. Imported Hubbard. Warty shell; green. Good keeper. Pkt., 10c.; Oz., 25c.; I/4 lb., 75c.; lb., \$2.25.

White Bush Scalloped. Pkt., 10c.; oz., 25c.; 1/4 lb., 75c.; 1b., \$2.25.

Yellow Bush Scalloped. Pkt., 10c.; oz., 25c.; 1/4 1b., 75c.; 1b., \$2.25.

\section{TOMATO}

Cherry. Fruit very small, cherry-red. Pkt., 10c.; oz., 90c.

Crimson Cushion. Fruit very large, brilliant crimson-scarlet; flesh solid. Pkt., 15c.; oz., $\$ 1.00$.

Dwarf Champion. Early. Smooth; purplish red; dwarf; compact grower. IPkt., 10c.; oz., 90c. 
TOMATO-Continued

Dwarf Stone. Of dwarf growth. Very productive. Fruit bright red. Resembles the original Stone in size and shape. Pkt., 10c.; oz., 80c.

Earliana. Claimed to be the earliest red tomato. Pkt., 10c.; oz., 80c.

John Baer. Early. Fruit of uniform size, brilliant red; very solid. Pkt., 10c.; oz., 80c.

Livingston's Globe. Fruit of large size; rose tinged scarlet; smooth; globe-shaped. Very productive. Pkt., 10c.; oz., 80c.

Livingston's Perfection. Early. Large; smooth. Very productive. Pkt., 10c.; oz., 70c.

Marglobe. A wonderful globe-shaped tomato. Fruit bright red; early, one of the best. Pkt., 15c.; oz., $\$ 1.00$.

Matchless. Cardinal-red; large; smooth; very solid. Pkt., 10c.; oz., 70c.

Ponderosa. Very large. Bright red. Pkt., 15c.; oz., $\$ 1.00$.

Stone. Deep red. One of the best and most reliable for main crop. Pkt., 10c.; oz., 90c.

Yellow Plum. A small yellow variety, resembling a plum in form and size. Pkt., 10c.; oz., 90c.

\section{TURNIP}

Early Purple Top Milan. Earlier than Red Top Strap Leaf. Pkt., 10c.; oz., 20c.; T/4 1b., 60c.; 1b., $\$ 1.75$.

Golden Ball. Bright yellow. Rapid grower. Excellent flavor. Pkt., 10c.; oz., 20c.; $1 / 4$ 1b., 50c.; 1b., $\$ 1.50$.

Purple Top Strap Leaf. For summer and fall use. Pkt., 10c.; oz., 15c.; 1 14 1b., 45c.; 1b., $\$ 1.25$.

Purple Top White Globe. Globe-shaped. Enormous cropper. Pkt., 10c.; oz., 15c.; 1/4 lb., 45c.; 1b., $\$ 1.25$.

Snowball. Early. Medium size; smooth; pure white skin and flesh. Pkt., 10c.; oz., 20c.; $1 / 4$ 1b., $50 \mathrm{c}$; $1 \mathrm{~b}$., $\$ 1.50$.

White Egg. Excellent for table. Smooth; white. Pkt., 10c.; oz., 15c.; 1/4 lb., 45c.; 1b., \$1.25.

Yellow Stone. The standard yellow sort for private or market use. Pkt., 10c.; oz., 15c.; 1/4 1b., 45c.; 1b., $\$ 1.25$.

TURNIP-Ruta Baga

Improved American Purple Top. Pkt., 10c.; oz., 20c.; $1 / 4$ lb., 50c.; 1b., $\$ 1.50$.

White Sweet, or Russian. Pkt., 10c.; oz., 20c.; T/4 1b., 50c.; 1b., $\$ 1.50$. 


\section{VEGETA B L E PLA N T S}

For convenience in handling them, the early cabbage, cauliflower, lettuce, pepper and tomato plants are grown in baskets. When grown in this way, the individual plants can be cut out when transplanted, and they are practically equal to pot-grown plants. This is a decided benefit to the purchaser.

\section{ASPARAGUS}

Palmetto. Selected three-year-old roots. $\$ 3.00$ per 100.

\section{CABBAGE}

Early; ready in April (transplanted). Grown in baskets.

Early Jersey Wakefield, Henderson's Early Summer. Baskets containing 12 plants each, 35c. per basket.

Late; ready in June.

Autumn King, Danish Ball Head, Drumhead Savoy, Mammoth Rock Red, Premium Flat Dutch, Volga. 20c. per dozen, $\$ 1.00$ per 100 .

\section{CAULIFLOWER}

Early; ready in April (transplanted). Grown in baskets.

Henderson's Early Snowball. Baskets containing 12 plants each, 35c. per basket.

\section{CELERY}

Ready in July (transplanted).

Easy Blanching, Giant Pascal, Golden Self-blanching, White Plume, Winter Queen. \$1.50 per 100.

\section{EGG PLANT}

Ready in May. Potgrown.

Black Beauty, New York Improved Spineless. Strong plants, in $3 \frac{1}{2}$-inch pots, $15 \mathrm{c}$. each.

\section{LETTUCE}

Early; ready in April (transplanted). Grown in baskets.

Black-seeded Simpson, Big Boston, May King. Baskets containing 12 plants each, 35c. per basket.

\section{PEPPER}

Ready in May (transplanted). Grown in baskets. Large Bell, or Bull Nose, and Ruby King. Baskets containing 12 plants each, 35c. per basket.

\section{RHUBARB}

Strong Roots. 35c. each, $\$ 3.50$ per dozen.

\section{TOMATO}

Ready in May (transplanted). Grown in baskets. Dwarf Champion, Earliana, Livingston's Globe, Marglobe, Matchless, Perfection, Ponderosa, Stone. Baskets containing 12 plants each, 35c. per basket. 


\section{G R A S S E E D}

\section{PIERSON'S PERFECTION LAWN GRASS SEED}

The best mixture made for lawns, grass plots, etc. Nothing adds so much to the beauty of a country place as a well-kept, velvety lawn. In order to secure this, it is necessary that the proper grasses should be sown. More disappointment results from sowing inferior seed than from any other cause.

Our Perfection mixture is composed of the finest American grasses in proper proportions of such kinds as are best adapted for our hot, dry summers, and will form a close, velvety lawn very quickly after being sown. Oats should never be sown with our mixture, as our seed comes up quick and strong, and is better without them. For new lawns, use 100 to $120 \mathrm{lbs}$. per acre. One pound will sow 300 to 400 square feet. Where quick results are wanted, the quantity should be increased. Lb., 60c.; 5 1bs., $\$ 2.75 ; 20$ lbs., $\$ 10.00 ; 100$ lbs., $\$ 45.00$.

\section{OUR SPECIAL MIXTURE FOR GOLF LINKS OR "PUTTING GREENS"}

This mixture will be found to be unexcelled. It contains the finest grasses, which make a close, firm, green, and lasting turf. Lb., 85c.; 5 1bs.,. $\$ 4.00 ; 20$ libs., $\$ 15.00 ; 100$ lbs., $\$ 70.00$.

\section{OUR SPECIAL MIXTURE FOR SHADY LAWNS}

A mixture of fine grasses that are best adapted and most suitable for growing in shady places, under trees or close to walls where there is little sun. Lb., 70c.; 5 lbs., $\$ 3.25 ; 20$ lbs., $\$ 12.00 ; 100$ 1bs., $\$ 50.00$.

\section{OUR SPECIAL MIXTURE FOR HAY AND PERMANENT PASTURE}

Much heavier hay crops can be produced and much better pasturage obtained where a mixture of the best grasses for these different purposes is used than when only one or two sorts are sown. We believe that the mixture offered by us will give particularly heavy crops of hay, and, after that, will afford most excellent and luxuriant pasturage, and will remain in good condition for a great length of time without the necessity of re-seeding. Our mixture will be found unexcelled for this purpose, and we can recommend it with the greatest confidence. It should be sown at the rate of $60 \mathrm{lbs}$. per acre, or, if quick results are wanted, a larger quantity can be sown. The thicker the seed is sown, the sooner a fine, close turf will be obtained. 20 lbs., $\$ 7.50 ; 100$ lbs., $\$ 35.00$.

$40 \mathrm{lbs}$. in a bag. Bags, 50c. extra. If sent by mail, postage must be added at parcel post zone rates. 


\section{CREEPING BENT GRASS}

20 lbs. to the bushel; 2 to 3 bushels to the acre.

Lb., $\$ 1.50 ; 20$ lbs., $\$ 25.00$.

\section{CRESTED DOG'S TAIL}

21 lbs. to the bushel; $1 \frac{1}{2}$ to 2 bushels to the acre. Lb., 65c.; 21 lbs., $\$ 12.60 ; 100$ lbs., $\$ 55.00$.

\section{KENTUCKY BLUE}

Fancy cleaned seed 14 1bs. to the bushel; $11 / 2$ bushels to the acre. Lb., 70c.; 14 lbs., $\$ 9.10 ; 100$ lbs., $\$ 60.00$.

\section{ORCHARD GRASS}

14 lbs. to the bushel; 3 to 4 bushels to the acre. Lb., 50c.; 14 1bs., \$6.30; 100 lbs., \$40.00.

\section{PERENNIAL RYE}

14 lbs. to the bushel; 4 to 5 bushels to the acre. Lb., 30c.; 14 lbs., $\$ 3.50$; 100 lbs., \$22.50.

\section{RED OR CREEPING FESCUE}

14 lbs. to the bushel; $1 \mathrm{I} / 2$ to 2 bushels to the acre. Lb., 65c.; 14 lbs., $\$ 8.40$; 100 lbs., $\$ 55.00$.

\section{RED TOP}

Fancy. 32 1bs. to the bushel. Lb., 45c.; 32 lbs., $\$ 12.80 ; 100$ 1bs., $\$ 35.00$.

\section{RHODE ISLAND BENT}

14 lbs. to the bushel; 2 to 3 bushels to the acre. Price on application.

\section{SHEEP'S FESCUE}

12 lbs. to the bushel; 3 bushels to the acre. Lb., 60c.; 12 lbs., $\$ 6.60 ; 100$ lbs., $\$ 50.00$.

\section{TIMOTHY}

45 lbs. to the bushel; I/2 bushel to the acre. Lb., 20c.; 45 1bs., $\$ 7.20 ; 100$ lbs., $\$ 14.00$.

\section{WOOD MEADOW GRASS}

14 1bs. to the bushel; 2 bushels to the acre. Lb., $\$ 1.00 ; 14$ lbs., $\$ 12.60$.

\section{CRIMSON CLOVER}

60 lbs. to the bushel; 20 lbs. to the acre. Lb., 35c.; 60 lbs., $\$ 16.50 ; 100$ lbs., $\$ 25.00$.

\section{RED CLOVER, Medium}

$60 \mathrm{lbs}$. to the bushel; 15 to $20 \mathrm{lbs}$. to the acre. Lb., 65 c.; 60 lbs., $\$ 34.50 ; 100$ lbs., $\$ 55.00$.

\section{WHITE CLOVER}

$60 \mathrm{lbs}$. to the bushel; 12 to $15 \mathrm{lbs}$. to the acre. Lb., $75 \mathrm{c}$; $60 \mathrm{lbs} ., \$ 40.50 ; 100 \mathrm{lbs}$., $\$ 65.00$.

Prices quoted on grass and clover seed are for best quality seed, and are subject to market changes. If cheaper grades are wanted, prices will be quoted on application. 
PURE BONE MEAL. Quick acting and immediately available, for which reason it is largely used for mixing in potting soil and for top dressing roses, carnations, and other plants grown under glass. It is also splendid for garden use. It is made from hard, dry bone, is perfectly pure and entirely free from acid, and can be used with perfect safety.

10 lbs., $\$ 1.00$; 25 lbs., $\$ 2.00$; bag (100 lbs.), $\$ 6.00$. Price per ton on application.

BLOOD AND BONE. A high-grade fertilizer of superior quality for enriching lawns and grass plots. Very desirable for quick and lasting results. Particularly valuable for all garden and farm crops, small fruits, fruit trees, etc.

10 lbs., $\$ 1.00$; 25 lbs., $\$ 2.00$; bag (100 lbs.), $\$ 6.00$; bag (167 lbs.), \$9.00. Price per ton on application.

CLAY'S FERTILIZER. A celebrated English fertilizer for garden and greenhouse use. Highly concentrated.

5 lbs., $\$ 1.00 ; 28$ lbs., $\$ 4.00 ; 112$ lbs., $\$ 12.00$.

FLORANID (Urea). A highly concentrated nitrogenous fertilizer containing 46 per cent of available nitrogen. It is clear, odorless and excellent for plants, fruit trees, lawns, shrubs, etc. It is 92 times stronger than manure.

Lb., 50c.; 5 lbs., $\$ 2.00 ; 10$ lbs., $\$ 3.00 ; 25$ lbs., $\$ 6.00$.

NITRATE OF SODA. A quick acting fertilizer. Can be used either dry or in liquid form. It supplies nitrogen to the soil.

5 lbs., 60c.; 25 lbs., $\$ 2.00$; bag (100 lbs.), $\$ 6.00$.

NITROPHOSKA. A very effective immediately available plant food. It contains 15 per cent nitrogen equivalent to 18.2 per cent Ammonia, 30 per cent phosphoric acid and 15 per cent potash. It contains three or four times as much available plant food as found in other fertilizers. It is very effective for greenhouse, vegetable garden, fruit trees, lawns, shrubs, etc.

Lb. carton, 35c.; 10 lb. bag, $\$ 2.50 ; 25$ lb. bag, $\$ 5.00$; 50 lb. bag, $\$ 9.00$.

PULVERIZED SHEEP MANURE. Fine for top dressing or for mixing with the soil for greenhouse or garden use; also for top dressing lawns, grass plots, etc., and for making liquid manure.

10 lbs., 80c.; 25 lbs., $\$ 1.50$; bag (100 lbs.), $\$ 4.50$. Price per ton on application.

STIM-U-PLANT. An odorless plant food in tablet form for fertilizing all kinds of growing plants in the home or garden. It is particularly desirable for use on all house plants.

Package containing 30 tablets, 25c.; 100 tablets, 75c.; 1,000 tablets, $\$ 3.50$.

\section{PRICES SUBJECT TO MARKET CHANGES}




\section{N S E C T I C I D E S}

ANSECT (Rose Bug Destroyer). For killing rose bugs, also very effective against red spider, aster beetle, leaf hopper, mealy bug, etc. $4 \mathrm{oz}$. can, 30c.; pint, $\$ 1.00$; quart, $\$ 1.50$; gallon, $\$ 5.00$.

ANT KILLER. Very effective for killing ants on lawns, golf courses, etc. Not mailable. 50c. per can; $\$ 5.50$ per dozen.

APHINE. Very effective for destroying all species of plant lice. Quart, \$1.00; gallon, $\$ 3.00$.

ARSENATE OF LEAD, POWDERED. For killing all leaf-eating insects. Not mailable. Lb., 50c.; 5 lbs., $\$ 2.25 ; 25$ lbs., $\$ 10.00$.

BLACK LEAF 40. A very effective insecticide for sucking insects, such as aphis, plant lice, red spider, etc. Not mailable. 1 -oz. bottle, $35 \mathrm{c}$.; $1 / 2-1 \mathrm{~b}$. tin, $\$ 1.25$; 2-1b. tin, $\$ 3.25$.

BORDEAUX MIXTURE, DRY. Not mailable. Lb., 40c.; 5 lbs., $\$ 1.80 ; 10$ lbs., $\$ 3.00 ; 25$ lbs., $\$ 6.50$.

CUT WORM KILLER. For use as poisonous bait against cut worms and slugs by placing around plants subject to attack. It has an enticing odor that worms prefer to vegetation. Not mailable. Lb., 50c.; 5 lbs., $\$ 2.00$.

FISH OIL SOAP. Concentrated. Lb., 40c.; 5 lbs., $\$ 1.80 ; 100$-lb. keg., $\$ 25.00$.

FLOUR OF SULPHUR. Lb., 15c.; 5 lbs., 60c.; 10 1bs., $\$ 1.00 ; 100$ lbs., $\$ 8.00$.

FUNGINE. For mildew, rust, and other blights. Quart, \$1.00; gallon, $\$ 3.00$.

GRAPE DUST. For mildew on roses, grapes, gooseberries, etc. Apply with bellows. 5-lb. package, $\$ 1.00$.

HELLEBORE, POWDERED WHITE. For currant worms, rose-leaf slugs, etc. Lb., 50c.; 5 lbs., $\$ 2.25$.

LEMON OIL. Pint, 75c.; quart, $\$ 1.25$; gallon, $\$ 3.50$.

LIME, SULPHUR, POWDERED. For San Jose scale, oyster-shell scale, etc. This should be applied when trees and shrubs are dormant. Not mailable. Lb., 40c.; 5 lbs., $\$ 1.80 ; 10$ lbs., $\$ 3.20$.

MELROSINE. A very effective insecticide which kills rose bugs, plant lice, black fly, green fly, soft scale insects, etc. Pint can, $\$ 1.00$; quart can, $\$ 1.75$; half-gallon can, $\$ 3.25$; gallon, $\$ 6.00$.

NICOFUME TOBACCO PAPER. A strong tobacco paper for fumigating greenhouses. 24 sheets, $\$ 1.25$; 144 sheets, $\$ 5.00 ; 288$ sheets, $\$ 9.00$.

NICOFUME LIQUID. For fumigating or spraying. Effectual for green fly, mealy bug, red spider, scale, thrip, etc. Not mailable. 1/4-1b. can, 75c.; 1b. can, $\$ 2.00$. 
PYROX. A very effective insecticide and fungicide for eating insects; also for preventing blights and fungus. Not mailable. 1-1b. bottle, 50c.; 5-1b. can, $\$ 2.00$.

SCALECIDE. For San Jose Scale and cottony maple scale, and other injurious insects that affect trees and shrubs. This should be applied when trees and shrubs are dormant. Quart, 75c.; gallon, $\$ 1.75$; 5gallon can, $\$ 6.25 ; 10$-gallon can, $\$ 10.60 ; 50$-gallon barrel, $\$ 38.00$.

SLUG SHOT. For currant worms, potato bugs, insects on cabbages, melons, cucumbers, etc. 5-1b. package, 65c. (Slug Shot Duster for applying Slug Shot, $75 \mathrm{c}$. each.)

SU-LI-NI. A combined insecticide and fungicide for destroying aphis, rose bugs, and other garden insects. Used for spraying for mildew, rust and blights. Not mailable. $1 / 2$-pint bottle, $75 \mathrm{c}$; ; quart, $\$ 2.50$.

VOLCK. An insecticide that controls aphis, scale, mealy bug, white fly, red spider and other insects. I/2-pint can, $50 \mathrm{c}$. ; pint can, $75 \mathrm{c}$.

WEED KILLER. For destroying weeds in gravel walks, drives, etc. Not mailable. 1-quart can, 70c.; 1 -gallon can, $\$ 2.00 ; 5$-gallon can, $\$ 7.50 ; 50$-gallon barrel, $\$ 45.00$.

WILSON'S O. K. PLANT SPRAY. Very effective for destroying all kinds of insects under glass or outside, also scale or mildew. Not mailable. Quart, $\$ 1.00$; gallon, $\$ 3.00$.

\section{GRE E N O U S E A N D G A R D E N S UP P L IES}

\section{FLOWER POTS}

We offer a very superior quality of flower pots. They are made of tough, fine clay, which makes them very strong and durable. The prices quoted on Standard Pots, Azalea Pots, and Bulb Pans are for local delivery, to points within reach of our delivery cars. Shipments in quantity to customers living at a distance outside of our delivery limits can be made by freight, direct from the factory, in which case $15 \%$ may be deducted from prices quoted; purchaser to pay freight and stand breakage.

\section{Standard Pots}

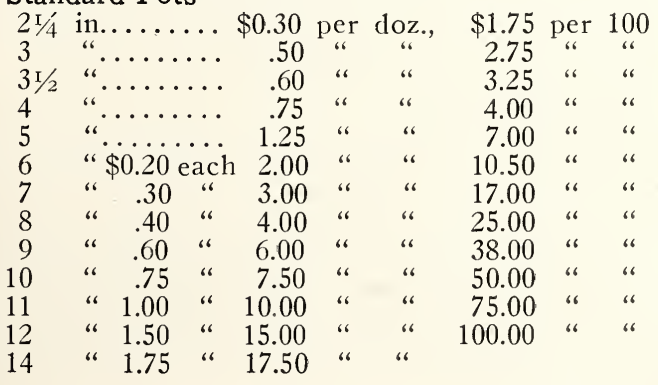


FLOWER POTS-Continued

Azalea Pots. These are three-fourths the depth of an ordinary pot. They are largely used for azaleas, ferns, etc. 6-, 8-, and 10-inch furnished at same prices as Standard Pots of corresponding sizes.

Bulb Pans, Round. These are very useful, especially for forcing bulbs. We find them particularly desirable for Nephrolepis ferns, being better adapted for these than Azalea Pots, 6-, 8-, 10-, 12-, and 14inch furnished at same prices as Standard Pots of corresponding sizes.

\section{BELLOWS}

Woodason's Improved. Large single cone. $\$ 5.00$ each.

\section{CARNATION SUPPORTS}

Model Extension. Three rings, $\$ 8.50$ per 100 .

\section{CUT FLOWER BOXES}

Folding Paper Boxes with Lock Corners. Made of manila cardboard. Oxford Gray outside. White inside. Very strong and durable. Occupy very little room when not in use. In lots of 250 and up, assorted sizes, we will print the name and address on the boxes without extra charge.

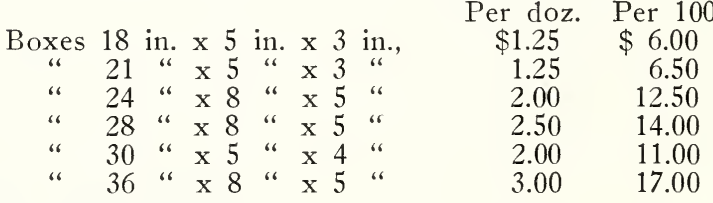

\section{GARDEN LINES}

Silver Lake. Best braided linen, 100 feet, $\$ 2.00$ each.

\section{GARDEN REELS}

Medium size, $\$ 1.75$ each.

\section{GRAFTING WAX}

Seal Bark. Lb., 60c.

\section{HANGING BASKETS}

Wire. Round. 10-in., 60c. each; 12-in., 75c.; 15-in., $\$ 1.00$.

\section{HORSE BOOTS}

Extra quality, hand-made, of the best leather. Large. $\$ 20.00$ per set of four boots.

\section{HOSE}

Extra quality.

Goodrich. 2-Braid. Extra quality, $5 / 8$ in., with $3 / 4$ in. couplings, $50-\mathrm{ft}$. lengths, $22 \mathrm{c}$. per foot. $3 / 4$-in. with $3 / 4$-in. couplings, $50-\mathrm{ft}$. lengths, $24 \mathrm{c}$. per foot.

\section{HOSE MENDERS}

Cooper's. A very fine hose mender. Simple and effective. For $1 / 2$-in. and $3 / 4$-in. hose. 15c. each, $\$ 1.50$ per dozen.

The Stulp. A very effective hose and pipe mender - can be used for mending either hose or pipe. It clamps around the outside of the hose or pipe, consequently does not stop the flow of the water. For $1 / 2$ - and $3 / 4$-in. hose or pipe. 15c. each, $\$ 1.50$ per dozen. 


\section{HOSE NOZZLE}

Knox Spraying. \$3.00 each; $\$ 33.00$ per dozen.

\section{HOT BED MATS}

Waterproof. One side waterproof, other side burlap. Heavily padded. Very warm. Made to cover two sashes. 76 in. x 76 in., $\$ 5.50$ each, $\$ 60.00$ per doz.

\section{LABELS}

Pot and Garden, painted

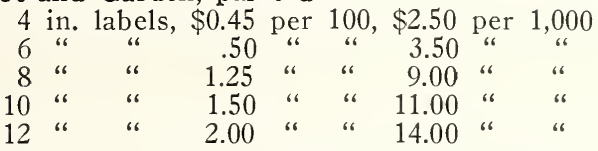

Tree Copper Wired. Ready for use. $3 \mathrm{r} / 2$-in., 50c. per $100, \$ 3.50$ per 1000 .

Copper. Indestructible. For labeling trees, shrubs, etc. Copper wired, ready for use. 31/2-in., 50c. per dozen, $\$ 3.00$ per 100 .

Pyralin. These labels are absolutely moisture and waterproof; instantly cleanable; will not split, tear or discolor; are lighter than wood and very attractive. Tree labels, 31/2-in. copper wired, $\$ 1.00$ per $100 ; \$ 6.50$ per 1000 .

\section{LAWN MOWERS}

Ideal Power Lawn Mower. We offer this mower in two sizes, 22 and 30 -inch cut, which are largely used on private estates, parks, golf courses, etc. The 30 -inch will cut six to seven acres per day. Loosely suspended cutting unit tilt to ride over any irregularity of ground. A general purpose mower that cuts close to trees, shrubbery and flower beds. Mechanically simple and easy to operate. The speed of this machine is $23 / 4$ miles per hour; diameter roller, 14 inch; diameter cutting reel, 6 inch; face mower wheels, 13/4 inch; actual weight, 630 lbs.; shipping weight, 800 lbs.; width roller, 24-inch; will cut, allowing 2 -in. lap, $3 / 4$ acre per hour; diameter mower wheels, 11 in.; number of cutting blades, 5 .

30 -inch cut, complete, $\$ 385.00$; riding attachment extra, $\$ 25.00$; extra cutting unit, $\$ 63.00$.

The 22-inch or Junior Ideal Power Mower: shipping weight, 575 lbs.; net weight, $430 \mathrm{lbs}$; diameter of reel, 6 inches; diameter of wheels, $10 \mathrm{I} / 2$ inches; total width of drive rollers, 17 inches. Price complete, $\$ 265.00$; extra cutting unit, $\$ 52.00$.

Regal Ball-Bearing, Five-Bladed, High-Wheel, 16-in. cut, $\$ 24.50 ; 18$-in., $\$ 26.00 ; 20$-in., $\$ 27.50$.

Imperial Roller Bearing, Five-Bladed, High-Wheel, 16-in., \$21.75; 18-in., \$23.25; 20-in., \$24.75.

Improved Excelsior Roller, Six Bladed. 14-in. cut, $\$ 38.00$; 16-in., \$40.00; 18-in., \$42.00.

Coldwell's Improved Horse, Five Bladed. With seat and shafts. 30 -in. cut, $\$ 160.00 ; 35$-in., $\$ 185.00 ; 40$-in., $\$ 210.00$. 


\section{LAWN ROLLERS}

Dunham Water-weight. These rollers are designed to be filled with water to any desired weight. They are equipped with a no-tip lock to hold the handles in position, and with a steel scraper, which can be let down on the drum to scrape off all grass, mud, etc. We offer two standard sizes-those most suitable for the average lawn. W B 5, 18 in. in diameter, 24 in. long, one section, weight empty, $85 \mathrm{lbs}$.; filled with water, 300 lbs., $\$ 22.00$. W B 7, 24 in. in diameter, 24 in. long, one section, weight empty, $110 \mathrm{lbs}$.; filled with water, 500 lbs., $\$ 26.00$.

Prices on larger and smaller sizes on application.

\section{MOLE TRAPS}

Schroeter. Best. $\$ 2.50$ each.

\section{MOSS}

Peat. Fine for mixing in soil and top dressing for lawns, etc. Per bale, about 200 lbs., $\$ 5.00$.

Sphagnum. For packing. $\$ 2.00$ per bbl.; burlapped bale of 5 bbls., $\$ 5.00$.

\section{PAPER}

Kraft. For wrapping. Sheets, size $30 \times 40$ in. and $40 \times 48$ in., 16c. per $1 \mathrm{~b}$.

White Tissue. Extra fine quality, size $20 \times 30$ in., 24 sheets, 25c.; ream, 480 sheets, $\$ 3.00$.

White Waxed Tissue. Finest quality. Excellent for packing cut flowers. Size, 24 x 36 in., 24 sheets, 35 c.; ream, 480 sheets, $\$ 4.00$.

\section{PLANT TUBS}

Richmond. These tubs are made of white cedar, painted green inside and out with flat steel hoops at bottom and galvanized wire hoops in middle and at top. Hoops do not rust. A very durable and a very neat and cheap plant tub.

Each

7 -in. inside top diam., 7 -in. inside depth, $\$ 0.80$

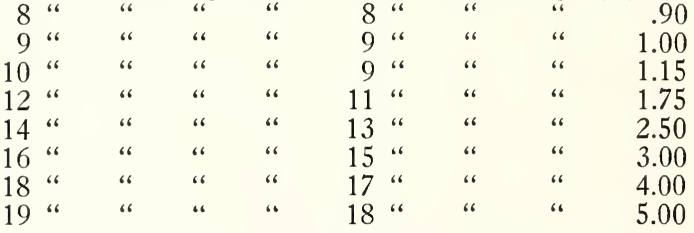

If stamped steel handles are desired, add $15 \mathrm{c}$. per tub extra.

\section{POLES, CEDAR}

We offer a fine lot of straight Cedar Bean Poles for staking climbing roses and other large plants, making arbors, etc. 12 to $14 \mathrm{ft}$. long, $\$ 9.00$ per dozen.

\section{RAPHIA}

West Coast. Finest grade. For tying, 50c. 1b.; 5 1bs., $\$ 2.25$. 


\section{RUBBER SPRINKLERS}

Scollay's. Large size, 12-oz., $\$ 1.75$ each. By mail, $\$ 1.85$.

\section{SASH, HOT BED}

Standard. We offer a fine lot of standard hot-bed sash $3 \mathrm{ft}$. wide, $6 \mathrm{ft}$. long, painted white, and glazed, f.o.b. factory or within reach of our local delivery limits. $\$ 8.00$ each. Packed for shipment, $\$ 1.50$ per crate additional.

\section{SHEARS}

Dental Snips. For cutting wire. Japanned handle, nickeled blade. 7 -in., $\$ 1.50$ each.

Wiss Pruning. Length, 9 inches. $\$ 3.50$ each.

Sheepshears. For trimming grass edges. 6-in., with extra heavy spring, $\$ 1.50$ each.

Hedge. Large size, durably made, the best. 10-in., with notch, $\$ 4.50$ each.

Grass Edging. For trimming the overhanging grass around the edges of walks, beds, etc. 9-in., $\$ 6.00$ each; with wheel, $\$ 6.50$.

\section{SILKALINE}

Green, for stringing smilax, asparagus, etc., 2-oz. spools, 50c. each; $\$ 3.50$ per $1 \mathrm{~b}$.

\section{SPRAYERS}

Auto Spray No. 1 B. Compressed Air Sprayer. This Compressed Air Sprayer has brass tank and is one of the best for spraying trees, shrubs, vines, field crops, greenhouses, etc. With Auto-Pop No. 1 nozzle. $\$ 10.00$ each.

Auto Spray No. 5. This pump is made entirely of brass, and is double-acting. It is an ideal sprayer for all purposes. The pump is furnished with two and a half feet of one-half inch suction hose, with a heavy strainer on an extension that will not work out of the bucket or tank when the pump is being used. Pump, hoze, nozzle complete. $\$ 5.50$ each. Brass extension rods, two-foot lengths, $60 \mathrm{c}$. each.

Auto Spray No. 26 C. A continuous atomizer for applying all solutions, insecticides, disinfectants, and is used satisfactorily in the greenhouse and garden. One quart, brass pump and brass reservoir, $\$ 2.25$ each.

New Era No. 23. Very useful hand Sprayer for spraying garden and farm vegetables, small fruit trees, shrubs, etc. The sprayer is made of brass and holds 3 quarts. All parts quickly accessible for cleaning and adjustment. $\$ 3.75$ each.

\section{STAKES}

Bamboo or Cane Iapanese Green Dyed. $3 \frac{1}{2} 2-\mathrm{ft} ., \$ 1.25$ per 100.

Bamboo or Cane Japanese Natural. 6-ft., $\$ 2.50$ per 100.

Galvanized Wire. The best of all stakes for roses. 3 -ft., $\$ 2.50$ per $100 ; 4$-ft., $\$ 3.00 ; 5$-ft., $\$ 4.00 ; 6$-ft., $\$ 5.00$. Dahlia Poles. Extra heavy; square tapering; painted green; 4-ft., $\$ 2.50$ per dozen; 5 -ft., $\$ 3.00$ per dozen; 6 -ft., $\$ 3.50$ per dozen. 


\section{SYRINGES}

No. 10. Best plate valve syringe. The finest syringe made. Length of barrel, 18 in.; diameter, $1 \frac{1}{2} \mathrm{in.}$ Highly polished, with one stream and two spray roses, one fine and one coarse. \$10.00 each.

\section{THERMOMETERS}

Cylindrical. Heavy brass tipped, for plunging in hot bed or cutting bench. $\$ 3.00$ each.

Special Greenhouse. Plain, tested, accurate, thermometers for conservatory or greenhouse use; 8-in., $\$ 1.25$ each.

\section{TIN-FOIL}

Green. 80c. per 1b.

Plain. 40c. per 1b.

Violet. $80 \mathrm{c}$. per $1 \mathrm{~b}$.

TOOTHPICKS, Wired

Hardwood. For stemming flowers. 15c. per 100; $\$ 1.00$ per 1,000 .

\section{TROWELS}

Good Quality. 6-in., 35c. each.

Extra Heavy. Steel, English. 6-in., 75c. each.

\section{TWINE}

Jute. 2-ply. Soft, for tying. 25c. per ball.

Linen. A very strong, smooth white twine. 50c. per ball.

Polished. 5-ply. Extra heavy. 50c. per ball.

Sea Island Green. Used for training smilax and for tying up packages. 20c. per ball.

\section{WATERING POTS, Galvanized}

Iron Horse. 8-qt., $\$ 2.00$ each; 10-qt., \$2.50 each.

\section{WEEDERS}

Excelsior. Saves the hands, and is much better and more thorough. 30c. each.

Hazeltine's. We can recommend this little tool as first-class in every way. 50c. each.

Magic. A combined weeder and hoe. A handy garden tool with four tines, made from the very best tempered steel wire, and provided with a blade or weed cutter. $60 \mathrm{c}$. each. The same with long handles, $\$ 1.25$ each.

\section{WIRE, Annealed}

Rose. Heavy. No. 23. Boxes of $12 \mathrm{lbs}$. each, in 12 - and 18 -inch lengths. $40 \mathrm{c}$. per $1 \mathrm{~b}$.; stone, $12 \mathrm{lbs}$, $\$ 4.00$. No. 25,45 c. per 1b.; stone, 12 lbs., $\$ 4.50$. 


\section{S U M M E R - F L O W E R I N G B U L B S}

DAHLIAS, Cactus and Hybrid Cactus

Aurora. Cream center, shading to amber and through tints of pink to white tips. 75c. each.

Decision. A splendid flower with long narrow incurved petals, shading from a deep yellow at the center to a clear bronze at the edges. A very free bloomer. 50c. each.

Garden Glow (Hybrid Cactus). A wonderful variety. Flowers orange-red and yellow. \$2.00 each.

George Walters. Flowers very large, full and wellformed, salmon rose shaded silvery pink. Wonderful bloomer. 50c. each.

Harpagon. Flowers clear yellow; always covered with bloom. $\$ 1.00$ each.

Jonkheer J. B. Von Tetz. A very fine free-flowering white variety. $\$ 1.00$ each.

Kalif. An enormous flower often measuring nine inches in diameter, of perfect form. Flowers pure scarlet. 75c. each.

Marguerite Bouchon. A beautiful shade of light pink with lighter center. One of the largest pink Cactus Dahlias. 75c. each.

Nagels Roem (Hybrid Cactus). Salmon pink suffused chamois. Long stiff stems; excellent keeper. $\$ 2.00$ each.

Renischer Frohsinn. A very distinct variety. The flowers are white at base of petals, changing about one-half their length to a carmine rose, making a very unique and attractive flower. 75c. each.

DAHLIAS, Decorative

Dr. Tevis. A wonderful decorative dahlia. In color, it is a beautiful shade of soft salmon, suffused with old gold shading to a golden apricot center. Flowers of immense size, of good form and borne on long stems. 75c. each.

Earl Williams. An exceptional variety. Flowers of the largest size; brilliant crimson-scarlet. Each petal tipped with white. An early and free bloomer. 75c. each.

Eldorado. A dwarf growing variety. Flowers immense golden-yellow. \$2.00 each. 
DAHLIAS, Decorative-Continued

Emma Marie. Flowers a lovely combination of bright pink and white; stems strong; very free flowering. $\$ 2.00$ each.

Firebrand. Flowers orange-carmine. Blooms well formed, large and carried on long, stiff stems. $\$ 1.50$ each.

Fordhook Victory. Flowers very large, well formed and carried on strong stems; a rich shade of Tyrian Pink. $\$ 3.00$ each.

Insulinda. The flowers are of large size; stems long and strong. It is much admired on account of the autumnal shades of the flower which are a beautiful orange buff overlaid with a golden sheen and shaded to a rich orange in the center. The reverse of the petals are old rose. $75 \mathrm{c}$. each.

Jersey Beauty. The finest pink dahlia. Flowers rose-pink of the largest size, borne on long, stiff stems-a really wonderful variety. 75c. each.

King of Autumn. Buff yellow suffused with terracotta, with good stem and foliage. 75c. each.

Lillian Baldwin. A very beautiful variety. Flowers rose pink; splendid keeper; good stem and habit. $\$ 2.50$ each.

Lucero. Flowers bronze buff with a carmine tint and a deeper tinted center. It has long stems and is fine for cutting. 50c. each.

Millionaire. The flowers immense in size; lavender shading to white. 75c. each.

Mont Blanc. An early, free, continuous bloomer. Flowers creamy white. 35c. each.

Mrs. Carl Salbach. This variety of California origin is an exceptional sort, a clean, vigorous grower of erect habit, producing flowers on unusually long, stiff stems, measuring nine inches across, solferino pink with white suffusion. 75c. each.

Mrs. I. De Ver Warner. One of the finest decorative varieties whether for exhibition or for garden decoration. Color deep mauve-pink or orchid pink. The flowers are large, of perfect form. An early and continuous bloomer. 75c. each.

Patrick O'Mara. Choice yellow; a good cut flower variety. $75 \mathrm{c}$. each.

Pride of California. Bright scarlet flowers of good size, produced on long, heavy stems. 75c. each.

Purity. Flowers pure white, large. 35c. each. 
Rosa Nell. A very fine decorative Dahlia. The flowers are a clear, bright rose. Very attractive; should be in every collection. 75c. each.

Sagamore. Bright amber-yellow shaded salmonrose. $\$ 1.50$ each.

Watchung Sunrise. Rich golden yellow suffused with amaranth pink. $\$ 5.00$ each.

DAHLIAS, Large-flowering or Show

A. D. Livoni. Clear, beautiful pink of medium size, beautifully quilled, of fine form. Very free flowering. 35c. each.

W. W. Rawson. A very fine Dahlia. Color white, shaded with lilac. 35c. each.

DAHLIAS, Pompon.

Atom. Flowers small, orange-red and yellow. $75 \mathrm{c}$. each.

Bacchus. Bright crimson scarlet. 50c. each.

Ideal. Fine clear yellow. 50c. each.

Little Mary. Dark rich crimson. 75c. each.

Neatness. Pale salmon with a cream center. 50c. each.

Pink Perfection. Flowers lovely deep pink. 50c. each.

Snowclad. 'Pure white. 50c. each.

Sunny Daybreak. Bright yellow edged red. 75c. each.

GLADIOLI, Named Varieties

Alice Tiplady. A magnificent primulinus variety. Flowers very showy, large, brilliant orange-saffron. $\$ 1.25$ per dozen, $\$ 7.00$ per 100 .

America. Exquisite, soft lavender-pink-about the same color as a cattleya. Extra fine for forcing or bedding. $\$ 1.00$ per dozen, $\$ 6.00$ per 100 .

Annie Wigman. Pure lemon with soft red blotch. $\$ 1.25$ per dozen, $\$ 8.00$ per 100 .

Evelyn Kirkland. A beautiful shade of rosy-pink, darker at the edges, shading to shell-pink with scarlet blotches on the lower petals. $\$ 1.25$ per dozen, $\$ 8.00$ per 100.

Herada. Blooms of immense size, pure mauve, with deeper markings in the throat. $\$ 1.50$ per dozen, $\$ 8.00$ per 100 .

Loveliness. A beautiful cream colored variety of good form and substance. $\$ 2.00$ per dozen, $\$ 12.50$ per 100. 


\section{GLADIOLI, Named Varieties-Continued}

Mary Pickford. A wonderful variety. Flowers are a delicate, creamy white. Throat, soft sulphur yellow; stem and calyx white. $\$ 1.25$ per dozen, $\$ 8.00$ per 100.

Mrs. Dr. Norton. La France-pink shading to very pale pink at the throat. $\$ 1.50$ per dozen, $\$ 9.00$ per 100.

Mrs. Francis King. Flowers brilliant vermilionscarlet, measuring four and a half inches across. Five to six flowers on a spike. A grand variety. $\$ 1.25$ per dozen, $\$ 7.00$ per 100 .

Mrs. Frank Pendleton. Flowers very large; beautiful salmon-pink, with rich maroon blotch on the lower petals. The flower spikes are strong and straight. $\$ 1.25$ per dozen, $\$ 8.00$ per 100 .

Myrtle. Clear, delicate rose-pink. One of the best pink sorts. $\$ 1.50$ per dozen, $\$ 9.00$ per 100 .

Niagara. A beautiful variety. Color soft primroseyellow, lightly marked and splashed rosy carmine in the throat. Flowers very large, measuring four and $\mathrm{a}$ half inches in diameter. $\$ 1.25$ per dozen, $\$ 8.00$ per 100 .

Panama. A charming variety. A seedling from America and an improvement on that variety, the color being deeper-a rich rose pink. \$1.00 per dozen, $\$ 6.00$ per 100 .

Peace. Flowers very large, of good form, white, with pale violet featherings on the lower petals. $\$ 1.25$ per dozen, $\$ 7.00$ per 100 .

Pink Perfection. A beautiful variety. Delicate apple-blossom pink. $\$ 1.50$ per dozen, $\$ 10.00$ per 100 .

Schwaben. Light orange-yellow with deep red blotch. $\$ 1.00$ per dozen, $\$ 6.00$ per 100 .

Primulinus Hybrids. Mixed. Extra choice. 80c. per dozen, $\$ 4.50$ per $100, \$ 35.00$ per 1,000 .

Extra Choice Mixed. Our own unrivaled mixture from named sorts. 80 c. per dozen, $\$ 4.50$ per 100 , $\$ 35.00$ per 1,000 .

\section{LILIES, Hardy}

Candidum (Annunciation Lily). Flowers snow white, fragrant, in clusters on stem, 3 to 4 feet high, in June. 40c. each, $\$ 4.00$ per dozen.

\section{MADEIRA VINE}

A very popular quick-growing climber. Selected roots. $15 \mathrm{c}$. each, $\$ 1.50$ per dozen.

\section{TUBEROSE, PEARL}

Extra quality bulbs, \$1.25 per dozen, $\$ 7.00$ per 100 . 


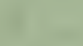

: 
MINDEN PRESS, INC. NEW YORK. N. Y 